\title{
REFORMA CONSTITUCIONAL, ASAMBLEA NACIONAL CONSTITUYENTE Y CONTROL JUDICIAL CONTENCIOSO ADMINISTRATIVO. EL CASO DE HONDURAS (2009) Y EL ANTECEDENTE VENEZOLANO (1999)*
}

\author{
Allan R. Brewer-Carías \\ Profesor de la Universidad Central de Venezuela \\ Adjunct Professor of Law, Columbia Law School (2006-2007)
}

\section{REFORMAS CONSTITUCIONALES Y CLÁUSULAS PÉTREAS}

Los mecanismos para la reforma de la Constitución en una sociedad democrática constituyen una de las piezas esenciales del Estado Constitucional, del Estado de derecho y de la democracia constitucional, ${ }^{1}$ pues al ser establecidos en la propia Constitución, la soberanía popular puede decirse que queda perfectamente juridificada; es decir, sujeta a limitaciones en cuanto a su manifestación, no sólo impuestas a los órganos del Estado mismo, sino al funcionamiento de la propia democracia y a la manifestación de dicha soberanía popular.

Por ello, si bien en la generalidad de las Constituciones, como por ejemplo ocurre en la de Honduras, se proclama que "la soberanía corresponde al pueblo del cual emanan todos los poderes del Estado", sin embargo, le imponen al propio pueblo, en su ejercicio, la observancia de las propias disposiciones constitucionales. Como dice el artículo 2 de la Constitución de Honduras: si bien del pueblo "emanan todos los Poderes del Estado", los mismos sólo "se ejercen por representación”.

* Trabajo escrito para el Libro Homenaje al profesor Juan Carlos Cajarville, Instituto Uruguayo de Derecho Administrativo, Montevideo, Uruguay.

1 Véase lo expuesto en Allan R. Brewer-CARías, "La reforma constitucional en una sociedad democrática" (Conferencia dictada en el acto de presentación del libro Visión y análisis comparativo de reformas constitucionales en Iberoamérica, Senado de la República Dominicana, Santo Domingo, 12 de julio de 2006), en Estudios sobre el Estado Constitucional (2005-2006), Editorial Jurídica Venezolana, Caracas, 2007, pp. 709-712. Véase también en www.allanbrewrercarias.com, Sección I, 1, 943 (2006). 
En esta forma, a la soberanía popular en las Constituciones se la ha dotado de un carácter jurídico y no sólo fáctico, lo que por supuesto no implica que se haga de la Constitución una fuente de la soberanía misma. El pueblo es el soberano y, como tal, es el que ha juridificado, al adoptar la Constitución, el ejercicio de su propia soberanía, otorgando además, a la misma de carácter supremo. En el Estado constitucional, por tanto, es el pueblo el que se autolimita a través de la Constitución adoptada como norma suprema para ejercer la soberanía; de manera que la Constitución normativiza su ejercicio.

Pero sin duda, la soberanía, a pesar de ser dotada en las Constituciones de ese carácter jurídico, en definitiva resulta ser un concepto político o una cuestión de hecho, cuyo ejercicio en una sociedad democrática tiene que tender a fundamentarse en el consenso político, para lograr que sea, precisamente, la expresión del pueblo. En otras palabras, el ejercicio de la soberanía popular en un Estado constitucional de derecho, nunca puede consistir en la imposición de la voluntad de una fracción sobre la otra. Tiene que buscar responder al consenso político, que por supuesto es cambiante, como también es cambiante el juego de las relaciones sociales y políticas.

La clave del éxito de las Constituciones, como normas dotadas de supremacía, en cualquier sociedad democrática es, precisamente, llegar a ser el resultado del consenso o de un pacto de toda una sociedad $-\mathrm{y}$ no de voluntades circunstanciales- $y$, además, poder prever en sus normas, tanto la forma de materialización de los cambios constitucionales, como los mecanismos que permitan garantizar, en su momento, que la voluntad popular no vaya a ser suplantada.

Por eso, la normativización de la soberanía popular, más que una limitación impuesta por el propio pueblo a su manifestación, es una garantía para que al pueblo pueda asegurársele la libre determinación de decidir su futuro. Por eso es que decimos que la juridificación de la soberanía popular implica su autolimitación procedimental, mediante el establecimiento de normas que aseguren efectivamente la formación de la voluntad soberana; normas precisamente como la que están en el artículo 373 de la Constitución de Honduras donde se precisa que una reforma constitucional sólo puede aprobarse cuando dos Legislaturas diferentes y subsecuentes la aprueben mediante voto calificado.

En general, por tanto, los procedimientos para la reforma constitucional establecidos en las Constituciones, constituyen una limitación adjetiva, autoimpuesta, para asegurar la manifestación de la voluntad popular; lo que sin embargo no excluye la posibilidad de que, como lo regulan muchas Constituciones, también se establezcan limitaciones de orden material, como cláusulas pétreas que buscan limitar el propio contenido de la voluntad popular, restringiendo su facultad de cambiar determinados principios e, incluso, sistemas políticos. Por ello el artículo 374 de la Constitución de Honduras dispone que no son reformables los artículos constitucionales que se refieren "a la forma de gobierno, al territorio nacional, al período presidencial, a la prohibición para ser nuevamente Presidente de la República, el ciudadano que lo haya desempeñado bajo cualquier título y referente a quienes no pueden ser Presidente de la República por el período subsiguiente". 
En todo caso, los mecanismos de reforma constitucional deben ser regulados en las Constituciones en forma tal que asegurando la manifestación de la voluntad popular (que en el caso de Honduras sólo es a través de sus representantes), a la vez, permita que se realicen los cambios necesarios que exige cualquier sociedad democrática.

Se trata, siempre, de la búsqueda del equilibrio entre soberanía popular y supremacía constitucional, que son los principios que siempre están presentes en toda reforma constitucional: Por una parte, la supremacía constitucional, que implica que la Constitución es la ley de leyes, que obliga por igual a gobernantes y gobernados, prescribiendo los mecanismos para la reforma constitucional como límites a los poderes constituidos y al propio pueblo; y por la otra, la soberanía popular que faculta al pueblo, como titular de la soberanía, el ejercicio del poder constituyente para modificar el Estado constitucional, su organización y la propia Constitución, en la forma prescrita en ella misma.

El primero, el principio de la supremacía constitucional, es un concepto jurídico; y el segundo, el de la soberanía popular, es un concepto político (aunque jurídificado); y en torno a ambos es que gira el poder constituyente, es decir, el poder de reformar la Constitución que siempre debe resultar de un punto de equilibrio entre ambos principios. Ni la supremacía constitucional puede impedir el ejercicio de la soberanía por el pueblo, ni este pueda expresarse al margen de la Constitución. En esta forma, en el equilibrio entre ambos principios, que es el equilibrio entre el derecho y los hechos, o entre el derecho y la política, es cómo el poder constituyente debe manifestarse en un Estado constitucional y democrático de derecho. Es decir, la reforma constitucional debe resultar del equilibrio previsto en la Constitución entre soberanía popular y supremacía constitucional, como juridificación del poder constituyente, para hacerlo operativo desde el punto de vista democrático.

Por todo lo anterior, puede decirse que la reforma de la Constitución o el poder de reforma constitucional, es un poder jurídico que descansa en un acto de autolimitación del poder constituyente el cual fija en el texto constitucional los mecanismos de actuación de ese poder de revisión. Por ello el artículo 375 de la Constitución de Honduras declara enfáticamente que ella en caso alguno pierde su vigencia ni deja de cumplirse "cuando fuere modificada por cualquier otro medio y procedimiento distintos del que ella mismo dispone".

Lo importante a destacar, en todo caso, es que esta juridificación o fijación jurídica no implica que la soberanía nacional, como poder constituyente, desaparezca. En realidad puede decirse que por la propia autolimitación constitucionalmente establecida, una vez regulado el poder constituyente en la Constitución, el mismo entra en un estado latente pero teniendo siempre la posibilidad de manifestarse cuando sea requerido, conforme al procedimiento que el mismo pueblo ha instituido en el texto constitucional.

Por ello la importancia que tiene para el Estado constitucional democrático de derecho que esta juridificación del poder constituyente sea, en definitiva, un instrumento para el fortalecimiento de la democracia. Se trata de la previsión, en forma de 
normas, de los mecanismos pacíficos y racionales para que el pueblo adopte en un momento y circunstancias determinadas el orden político y jurídico apropiado para sus fines esenciales. De allí la posibilidad misma de plantear el mecanismo constitucional de la Asamblea Constituyente para la reforma de la Constitución, pero para ello, obviamente, el mismo tiene que ser previamente juridificada.

En todo caso, cualquiera que sea el procedimiento constitucionalmente establecido para la reforma constitucional, el mismo debe garantizar la manifestación democrática de la voluntad popular en el marco constitucional, y evitar que por la fuerza o por la expresión de mayorías circunstanciales se imponga la voluntad de una facción del pueblo sobre las otras. La historia, por lo demás, enseña que nada que se imponga a una sociedad por la fuerza perdura; ni nada que pretenda basarse en la imposición de la voluntad de una facción de la sociedad aplastando o excluyendo a las otras, perdura.

Una reforma constitucional, por tanto, para que perdure, por sobre todo tiene que ser un instrumento para la inclusión, el consenso y la conciliación. Es cierto que a veces ha sido el resultado de un armisticio después de alguna guerra fraticida, como tantos ejemplos nos muestra la historia; en otros casos, ha sido el resultado de un pacto para evitar la confrontación, como también nos lo muestra la historia reciente. Pero en todo caso, debe ser un instrumento de conciliación, que permita no sólo adaptar las Constituciones a las exigencias políticas de los tiempos contemporáneos, sino que las mismas sean efectivamente la manifestación de la voluntad popular. Ese es el reto que todo país tiene al plantearse el tema de la reforma constitucional, cuya asunción tiene que garantizar la perdurabilidad de la democracia, perfeccionándola para todos.

En el caso de Honduras, la Constitución es de los pocos textos constitucionales latinoamericanos que establece mecanismos relativamente sencillos para su reforma, excluyendo la intervención del pueblo en el procedimiento de reforma, lo que al contrario, en la mayoría de los países latinoamericanos se requiere expresamente mediante la aprobación de las reformas por referendo. En efecto, en Honduras, de acuerdo con el artículo 373 de la Constitución, la adopción de las reformas constitucionales corresponde al Congreso, como cuerpo de la representación del pueblo, al cual este le asignó el carácter de poder constituyente derivado, pudiendo en tal carácter decretar dichas reformas en sesiones ordinarias, aun cuando con el voto de los dos tercios de la totalidad de sus miembros. Ese es el primer elemento de rigidez constitucional que se establece en la Constitución, seguido de otro y es que las reformas adoptadas sólo pueden entrar en vigencia una vez que sean ratificadas por la subsiguiente legislatura ordinaria, por igual número de votos. En consecuencia, en Honduras no hay otro mecanismo para reformar la Constitución que no sea el Congreso mediante el procedimiento especial mencionado, lo que implica la necesidad de lograr consensos entre los representantes del pueblo, mediante voto calificado, ni siquiera una sola vez, sino dos veces: primero por el Congreso que sancionó inicialmente la reforma y segundo, por el nuevo Congreso electo subsecuentemente.

Esta forma relativamente sencilla del procedimiento de reforma constitucional, por otra parte, tiene como contrapartida la inclusión en la Constitución de una sustancial 
cláusula pétrea referida a diversos aspectos constitucionales sustantivos que no pueden reformarse en la forma prevista. Es el caso mencionado del artículo 374 de la Constitución de Honduras el cual dispone que no son reformables mediante el mencionado procedimiento de reforma constitucional "los artículos constitucionales que se refieren a la forma de gobierno, al territorio nacional, al período presidencial, a la prohibición para ser nuevamente Presidente de la República, el ciudadano que lo haya desempeñado bajo cualquier título y referente a quienes no pueden ser Presidente de la República por el período subsiguiente”.

Una norma de este tipo, como se dijo, no es frecuente en América Latina, ${ }^{2}$ y quizás es sólo comparable con las previsiones de la Constitución de Guatemala donde también se establece en el artículo 281 de la Constitución que "en ningún caso podrán reformarse los artículos 140 (independencia del Estado y al sistema de gobierno), 141 (soberanía popular), 165, inciso g) (desconocimiento del mandato del Presidente después de vencido su período constitucional), 186 (prohibiciones para optar a cargos de Presidente y Vicepresidente) y 187 (prohibición de reelección), ni en forma alguna toda cuestión que se refiera a la forma republicana de gobierno, al principio de no reelección para el ejercicio de la Presidencia de la República, ni restársele efectividad o vigencia a los artículos que estatuyen alternabilidad en el ejercicio de la Presidencia de la República, así como tampoco dejárseles en suspenso o de cualquier otra manera de variar o modificar su contenido".

En otros países las cláusulas pétreas son más limitadas, como sucede por ejemplo en El Salvador, donde el artículo 248 constitucional dispone que: "No podrán reformarse en ningún caso los artículos de esta Constitución que se refieren a la forma y sistema de gobierno, al territorio de la República y a la alternabilidad en el ejercicio de la Presidencia de la República”. En sentido similar, aun cuando sin referencia al principio de la alternabilidad, el artículo 119 de la Constitución de República Dominicana declara que: "Ninguna reforma podrá versar sobre la forma de Gobierno, que deberá ser siempre civil, republicano, democrático y representativo". En otros casos, como en la Constitución del Brasil, lo que se establece es que no se puede abolir determinadas instituciones o principios, pero ello no impide la reforma de los artículos que las consagran. En tal sentido, el artículo 60 § 4, establece que: "No será objeto de deliberación la propuesta de enmienda tendiente a abolir: I. La forma federal del Estado; II. El voto directo, secreto, universal y periódico; III. La separación de los Poderes; IV. Los derechos y garantías individuales".

En el artículo 137 de la Constitución de Cuba también se ha establecido una cláusula pétrea respecto del "sistema político, económico y social, cuyo carácter irrevocable lo establece el artículo 3 del Capítulo I, y la prohibición de negociar acuerdos bajo

2 Véase Allan R. Brewer-Carías, "Modelos de revisión constitucional en América Latina”, en Boletín de la Academia de Ciencias Políticas y Sociales, enero-diciembre 2003, N 141, Caracas, 2004, pp.115-156; y en Walter Carnota y Patricio Marianello (Directores), Derechos Fundamentales, Derecho Constitucional y Procesal Constitucional, Editorial San Marcos, Lima, 2008, pp. 210-251. 
agresión, amenaza o coerción de una potencia extranjera”. Además, en la reforma constitucional de junio de 2002, la Asamblea Nacional del Poder Popular añadió al texto constitucional otra cláusula pétrea con el siguiente texto:

"Disposición Especial. El pueblo de Cuba, casi en su totalidad, expresó entre los días 15 y 18 de junio del 2002, su más decidido apoyo al proyecto de reforma constitucional propuesto por las organizaciones de masas en asamblea extraordinaria de todas sus direcciones nacionales que había tenido lugar el día 10 del propio mes de junio, en el cual se ratifica en todas sus partes la Constitución de la República y se propone que el carácter socialista y el sistema político y social contenido en ella sean declarados irrevocables, como digna y categórica respuesta a las exigencias y amenazas del gobierno imperialista de los Estados Unidos el 20 de mayo de 2002 ".

Estas cláusulas pétreas, por otra parte, en algunas Constituciones se regulan, aun cuando no en la forma tan clara y precisa de los ejemplos mencionados, sino que se deducen la forma de redacción de las propias disposiciones constitucionales, como sucede por ejemplo, en el artículo 1 de la Constitución de Venezuela cuando declara que la República "es irrevocablemente libre e independiente..."; cuando el artículo 5 que declara que "la soberanía reside intransferiblemente en el pueblo", o cuando el artículo 6 prescribe que el gobierno de la República "y de las entidades políticas que la componen es y será siempre democrático, participativo, electivo, descentralizado, alternativo, responsable, pluralista y de mandatos revocables". ${ }^{3}$

Otra cláusula pétrea incluso puede identificarse como consecuencia de la previsión del principio de la progresividad en materia de derechos humanos, como lo establece el artículo 19 de la Constitución de Venezuela, lo que implica que las normas que prevén la protección constitucional de los derechos inherentes a la persona humana, nunca podrían reformarse para reducir el ámbito de protección de los mismos.

La diferencia entre las previsiones para la reforma constitucional y las cláusulas pétreas establecidas en muchas de las Constituciones latinoamericanas con las establecidas en la Constitución de Honduras, es que en todo caso, en esta última está prevista la consecuencia de la violación de las normas constitucionales en la materia. Por ejemplo, en materia de limitación a la reelección presidencial que se prevé en la Constitución y a la mencionada cláusula pétrea que declara como no reformable la norma del artículo 239 que dispone que "el ciudadano que haya desempeñado la titularidad del Poder Ejecutivo no podrá ser Presidente o Designado”, es ella misma la que dispone la consecuencia de su violación al prever que "El que quebrante esta disposición o proponga su reforma, así como aquellos que lo apoyen directa o indirectamente, cesarán de inmediato en el desempeño de sus respectivos cargos, y quedarán inhabilitados por diez años para el ejercicio de toda función pública”.

Véase sobre el principio de la alternabilidad republicana en Venezuela, en Allan R. BREWER-CARíAs, "El Juez Constitucional vs. La alternabilidad Republicana. (La reelección continua e indefinida)", en Revista de Derecho Público, № 117, Editorial Jurídica Venezolana, Caracas, 2009, pp. 205 ss. 
Además, el artículo 4 de la misma Constitución después de declarar que "la forma de gobierno es republicana, democrática y representativa" agrega que "la alternabilidad en el ejercicio de la Presidencia de la República es obligatoria”, disponiendo que "La infracción de esta norma constituye delito de traición a la Patria". Llega tan lejos la Constitución de Honduras en esta materia que prevé en su artículo 42,5 como una de las causales de la pérdida de "la calidad de ciudadano", el hecho de "incitar, promover o apoyar el continuismo o la reelección del Presidente de la República”.

Ese es el contexto jurídico constitucional en el cual el Presidente Manuel Zelaya comenzó a plantear la posibilidad de proceder a convocar una Asamblea Nacional Constituyente como mecanismo de reforma no previsto ni regulado en la Constitución (entre otros aspectos para incluir la reelección indefinida del Presidente de la República), sin duda, tratando de seguir los pasos diseñados en el precedente venezolano de 1999 , donde forzando la realización de un "referendo consultivo" (no vinculante) sobre el mismo tema de la convocatoria de una Asamblea Constituyente, una vez realizada la consulta se puso en juego el conflicto entre soberanía popular y supremacía constitucional, tácticamente prevaleciendo la primera a través de interpretaciones constitucionales tortuosas, que dieron origen a una Asamblea Constituyente que en definitiva comenzó por dar un golpe de Estado contra la Constitución y los poderes constituidos, en nombre de la soberanía popular que asumió y usurpó.

\section{EL ANTECEDENTE VENEZOLANO EN 1999 DE LA CONSULTA POPULAR SOBRE LA CONVOCATORIA DE UNA ASAMBLEA CONSTITUYENTE NO PREVISTA EN LA CONSTITUCIÓN Y LA AMBIGUA INTERPRETACIÓN JUDICIAL POR LA JURISDICCIÓN CONTENCIOSO ADMINISTRATIVA}

En efecto, durante la campaña electoral presidencial de 1998, el entonces candidato Hugo Chávez Frías propuso al electorado como su fundamental propuesta política sobre el Estado, la convocatoria de una Asamblea Nacional Constituyente para "refundar el Estado”, la cual, sin embargo, no estaba prevista en la Constitución de 1961 como un procedimiento válido para la reforma constitucional. La Constitución, en realidad sólo establecía expresamente dos mecanismos para su revisión, que eran la "enmienda" y la "reforma general". ${ }^{4}$ Una Asamblea Constituyente cuando no es producto de un golpe de Estado o una ruptura fáctica del orden constitucional, para poder ser convocada tiene que estar regulada constitucionalmente como mecanismo para la reforma de la Constitución, como a partir de la Constitución de 1999 se estableció

\footnotetext{
4 Véase sobre estas previsiones Allan R. BREWER-CARÍAs, "Los procedimientos de revisión constitucional en Venezuela" en Boletín de la Academia de Ciencias Políticas y Sociales, N 134, Caracas 1997, pp. 169222; y en Eduardo Rozo AcuÑA (Coord.), I Procedimenti di revisione costituzionale nel Diritto Comparato, Atti del Convegno Internazionale organizzato dalla Facoltà di Giurisprudenza di Urbino, 23-24 aprile 1997, a cargo del Prof., Università Degli Studi di Urbino, pubblicazioni della Facoltà di Giurisprudenza e della Facoltá di Scienze Politiche, Urbino, Italia, 1999, pp. 137-181.
} 
expresamente en Venezuela. ${ }^{5}$ En 1998, por tanto, ante la propuesta del entonces Presidente electo Hugo Chávez Frías sobre la Asamblea Constituyente, el problema era cómo elegirla.

Sobre ello, a comienzos de 1999, decíamos lo siguiente:

El reto que tenemos los venezolanos hacia el futuro, incluyendo el presidente electo Hugo Chávez Frías y su futuro gobierno, por tanto, no es resolver si vamos o no a tener una Asamblea Constituyente en el futuro próximo, sino cómo la vamos a realizar. Las elecciones de noviembre y diciembre de 1998 iniciaron el proceso, pero el dilema es el mismo de siempre: ¿la vamos a convocar violando la Constitución o la vamos a convocar respetando la Constitución? En el pasado, por la fuerza, siempre hemos optado por la primera vía; en el momento presente, con la globalización democrática que caracteriza al mundo contemporáneo y con el desarrollo político de nuestro propio pueblo, no habría derecho a que el nuevo gobierno y los partidos tradicionales, por su incomprensión, también nos lleven a tomar la vía del desprecio a la Constitución, precisamente, la "fulana Constitución", como se la ha calificado recientemente.

Las fuerzas políticas tradicionales representadas en el Congreso tienen que aceptar que el sistema político iniciado en los años cuarenta, sencillamente terminó, y tienen que entender que el precio que tienen que pagar por mantener la democracia, consecuencia de su incomprensión pasada, es reformar de inmediato la Constitución para establecer el régimen de la Asamblea Constituyente, en la cual, sin duda, nuevamente perderán cuotas de poder.

Pero las nuevas fuerzas políticas también representadas en el Congreso, y el presidente electo Hugo Chávez Frías, también tienen que entender que la Constitución no está muerta, que es el único conjunto normativo que rige a todos los venezolanos y que su violación por la cúpula del poder lo único que lograría sería abrir el camino a la anarquía.

Los venezolanos de comienzos del siglo XXI no nos merecemos una ruptura constitucional y tenemos que exigir que la inevitable y necesaria Asamblea Constituyente se convoque y elija lo más pronto posible, pero mediante un régimen establecido constitucionalmente, pues no hay otra forma que no sea mediante una reforma de la Constitución para establecer la forma de la Asamblea (unicameral o no), el número de sus integrantes, las condiciones y forma de su elección y postulación (uninominal o no) su rol democrático y su relación con los principios republicanos y de la democracia representativa, incluyendo, la separación de los Poderes Públicos.

Ninguna otra autoridad o poder del Estado puede establecer ese régimen y menos aún puede ser el resultado de una consulta popular o referéndum consultivo. Este para

5 Véase los comentarios sobre los mecanismos de reforma de la Constitución en la Constitución de 1999 en Allan R. Brewer-Carías, La Constitución de 1999. Derecho Constitucional Venezolano, Editorial Jurídica Venezolana, Tomo I, Caracas, 2004, pp. 157 ss. 
lo único que sirve es para obtener un mandato popular que habría que actualizar constitucionalmente, mediante una reforma del Texto Fundamental. De lo contrario sería como si se pretendiera establecer la pena de muerte, prohibida en el artículo 51 de la Constitución, mediante un simple "referéndum consultivo". Si éste se realizase, lo único que significaría sería la expresión de una voluntad popular que habría de plasmarse en la reforma constitucional del artículo 51 de la Constitución, pero no podría nunca considerarse, en sí mismo, como una reforma a la Constitución.

Lo mismo sucede con el tema de la Asamblea Constituyente: la elección de Hugo Chávez Frías puede considerarse como la expresión de una voluntad popular pro constituyente que debe plasmarse en la Constitución mediante su reforma específica. Por ello, si el 23 de enero próximo el Congreso inicia la reforma específica de la Constitución para establecer el régimen de la Constituyente, para cuando se realice el referéndum consultivo prometido por el Presidente electo (60 días después del 15 de febrero, es decir, el 15 de abril) podría en realidad realizarse el referéndum aprobatorio de la reforma constitucional que regule la Constituyente y procederse a su convocatoria.

Esta es una fórmula para resolver el tema de la constitucionalización de la Asamblea Constituyente, la cual es indispensable para poder convocarla democráticamente, es decir, en el marco de la Constitución, conforme a la cual fue electo presidente Hugo Chávez Frías y se juramentará próximamente en su cargo". ${ }^{\circ}$

Por tanto, a comienzos de 1999, aún bajo la vigencia de la Constitución de 1961, la única forma de poder convocar una Asamblea Constituyente en Venezuela, era reformando la Constitución para regularla, y si no se reformaba la Constitución, era si ello resultaba de alguna interpretación judicial que se hiciese de la Constitución por parte de la Corte Suprema de Justicia, como juez constitucional, para precisamente, evitar que ocurriera una confrontación fáctica entre el principio de la soberanía popular y el principio de la supremacía constitucional. Y ello fue lo que se pretendió obtener mediante el ejercicio, en 1998, de dos recursos de interpretación sobre los alcances del "referendo consultivo" que entonces sólo estaba previsto en la Ley Orgánica del Sufragio y Participación Política de 1998, que fueron interpuestos por ante la Sala Político Administrativa (Contencioso-administrativa) de la antigua Corte Suprema de Justicia en 1998, de los cuales sin embargo, y lamentablemente, no resultó decisión judicial expresa alguna.

La Sala, en efecto, dictó sendas sentencias el 19 de enero de $1999,{ }^{7}$ con contenido ambiguo, en el cual no se decidió con precisión lo que se le había consultado; lo que no impidió que las decisiones fueran "interpretadas" como la supuesta solución al

6 Véase Allan R. Brewer-Carías, (sobre la Asamblea Constituyente) "Necesaria e inevitable", en El Universal, Caracas, 19-01-1999, pp. 1-14.

7 Véase el texto en Revista de Derecho Público, No 78-80, Editorial Jurídica Venezolana, Caracas 1999 , pp. 55-73. Véase los comentarios a dichas sentencias en Allan R. BreWER-CARías, "La configuración judicial del proceso constituyente o de cómo el guardián de la Constitución abrió el camino para su violación y para su propia extinción", en Idem, pp. 453 ss.; y en Allan R. Brewer-Carías, Asamblea Constituyente y Ordenamiento Constitucional, Academia de Ciencias Políticas y Sociales, Caracas, 1999, pp. 151 ss. 
conflicto constitucional existente, dando lugar, como consecuencia de un "referendo consultivo", a la subsecuente convocatoria, elección y constitución de una Asamblea Nacional, lo que en todo caso ocurrió en democracia y sin ruptura constitucional a la usanza tradicional.

Pero la verdad, es que no hubo tal interpretación constitucional, ya que el juez contencioso administrativo renunció a ejercer su función interpretativa, de lo cual resultó que, en definitiva, la ruptura constitucional o golpe de Estado en Venezuela la terminó dando la propia Asamblea Nacional Constituyente una vez que fue electa el 25 de julio de 1999, al irrumpir desde el mismo momento de su constitución el 8 de agosto de 1999, contra la Constitución de $1961,{ }^{8}$ interviniendo los poderes constituidos sin autoridad alguna para ello, incluyendo la propia Corte Suprema que le había dado nacimiento, la cual también terminó siendo eliminada.

El tema que debió haber resuelto la Corte Suprema y que renunció a hacer, era el que resultaba del debate político que existía a comienzos de 1999 y que se le había planteado para que interpretara, sobre la forma de convocar la Asamblea Constituyente que tanto había prometido el Presidente electo, en el sentido de que: o se reformaba previamente la Constitución para regularla y luego elegía, como planteábamos; ' o se convocaba sin regularla previamente en la Constitución, sólo apelando a la soberanía popular al margen de las previsiones constitucionales ${ }^{10}$ como lo planteaba el Presidente electo. Se trataba, en definitiva de resolver el conflicto constitucional mencionado entre supremacía constitucional y soberanía popular, que la Corte Suprema tenía que enfrentar y asumir, pues sólo el juez contencioso administrativo actuando como juez constitucional podía hacerlo.

Sin embargo, aun antes de que se pudiera asumir que la Corte Suprema habría resuelto el conflicto, lo cierto es que el Presidente electo había optado pública y abiertamente por la segunda vía, anunciando públicamente su decisión de convocar la Asamblea Constituyente apenas asumiera la Presidencia de la República, el 2 de febrero de 1999, sin necesidad de reformar previamente la Constitución de 1961 para regularla. Durante esos días, en todo caso apoyado por la popularidad que en ese momento tenía, formuló amenazas y ejerció indebida y públicamente presiones contra la Corte Suprema de Justicia buscando apoyo de su propuesta. ${ }^{11}$

8 Véase en general, Allan R. Brewer-Carías, Golpe de Estado y Proceso Constituyente en Venezuela, UNAM, México 2002.

9 Véase en Allan R. Brewer-Carías, Asamblea Constituyente y Ordenamiento..., cit., pp. 153 a 227 ; Allan R. BreWER-CARÍAs, "El desequilibrio entre soberanía popular y supremacía constitucional y la salida constituyente en Venezuela en 1999, en Revista Anuario Iberoamericano de Justicia Constitucional, $\mathrm{N}^{\circ} 3$, 1999, Centro de Estudios Políticos y Constitucionales, Madrid, 2000, pp. 31-56.

10 Sobre los problemas jurídicos que precedieron a la conformación de la Asamblea Nacional Constituyente, véase Hildegard Rondón de Sansó, Análisis de la Constitución venezolana de 1999, Editorial Ex Libris, Caracas, 2001, pp. 3-23.

11 Véase las críticas que expresamos en su momento a las presiones presidenciales al Poder Judicial, en Allan R. Brewer-CaríAs, "Expresiones de Chávez atentan contra independencia del Poder Judicial”, en Cambio. Mérida, 14 de febrero de 1999, p. 3; y en Frontera. Mérida, 14 de febrero de 1999, p. 3-A. 
La propuesta presidencial, en todo caso, consistía en utilizar ilegítimamente la vía de un referendo consultivo previsto en una ley para convertirlo en un "referendo decisorio", en fraude a la Constitución. En 1999, por ello, indicábamos que

"La convocatoria a dicha Asamblea Constituyente, sin estar prevista en la Constitución, siempre consideramos que no sería otra cosa que un desconocimiento de la Constitución de 1961. En efecto, el referéndum consultivo que prevé el artículo 181 de la Ley Orgánica del Sufragio es un medio de participación popular de carácter consultivo y no de orden decisorio. Es evidente que una consulta al pueblo nunca podría considerarse inconstitucional, pues es una manifestación de la democracia. Pero pretender que mediante una consulta popular pudiera crearse un órgano constitucional, como la Asamblea Constituyente, establecerse su régimen y que pudiera proceder a realizar la reforma constitucional eso sí podía considerarse inconstitucional, pues ello implicaría reformar la Constitución, y para ello, habría que seguir ineludiblemente el procedimiento pautado en el artículo 246 que exige la actuación del Poder Constituyente Instituido que implica, incluso, que la reforma sancionada se someta a un referéndum aprobatorio. Sustituir todo ello por un referéndum consultivo podía considerarse como una violación de la Constitución.

El referéndum consultivo, en realidad, sólo es eso, una consulta que se traduce en la manifestación de un mandato político que debe ser seguido por los órganos constitucionales para reformar la Constitución y regular lo que la consulta popular propone. Pero pretender que con la sola consulta popular se pudiera crear un nuevo Poder Constituyente de reforma, podía significar el desconocimiento de la Constitución y la apertura del camino de la anarquía.

El problema constitucional que estaba planteado, sin embargo, sólo podía ser resuelto por la Corte Suprema de Justicia, y así ocurrió con las mencionadas sentencias del 19-01-99". ${ }^{2}$

En efecto, como se dijo, para diciembre de 1998, la Corte Suprema conocía de sendos recursos de interpretación que habían sido intentados para que resolviera, justamente, sobre si era necesario o no reformar la Constitución para regular la Asamblea Constituyente para poder ser convocada. El resultado de la presión política que se originó, fue precisamente la emisión de las dos mencionadas sentencias por la Corte Suprema, el 19 de enero de 1999, dos semanas antes de que el Presidente electo tomara posesión de su cargo, en las cuales la Corte Suprema, sin resolver expresamente lo que se le había solicitado interpretar, sin embargo se refirió ampliamente al derecho constitucional a la participación política y glosó también ampliamente, aun cuando en forma teórica, la doctrina constitucional sobre el poder constituyente, desencadenando así el proceso que luego no pudo ni contener ni limitar, costándole como se dijo, su propia existencia.

12 Véase en Allan R. Brewer-Carías, Asamblea Constituyente y Ordenamiento..., cit., pp. 181-182. 
En relación con el mencionado dilema que existía en ese momento político entre supremacía constitucional y soberanía popular, de la interpretación que se dio a las mencionadas sentencias de la Corte Suprema sobre si se podía convocar un referéndum consultivo sobre la Asamblea Constituyente, en definitiva se dedujo que la misma se podía crear mediante la sola manifestación de esa voluntad popular consultiva, aunque fuera expresada al margen de la Constitución de 1961, sin que ésta se reformara previamente.

El tema que tenía que enfrentar la Corte Suprema era dilucidar cuál principio de los dos que constituyen los dos pilares fundamentales que rigen al Estado Constitucional, debía prevalecer en Venezuela en ese momento: o el principio democrático representativo o el principio de la supremacía constitucional, lo que en todo caso exigía que se mantuviera el equilibrio entre ambos. ${ }^{13}$ En ese dilema, si la Corte se atenía al solo principio democrático de democracia representativa que está a la base del Estado constitucional, el pueblo soberano sólo podía manifestarse como poder constituyente instituido mediante los mecanismos de modificación constitucional previstos en la Constitución de 1961 (art. 246). Sin embargo, de acuerdo con lo expresado por la Corte Suprema de Justicia en su mencionada sentencia, "Si la Constitución, como norma suprema y fundamental puede prever y organizar sus propios procesos de transformación y cambio..., el principio democrático quedaría convertido en una mera declaración retórica...". Es decir, conforme a esa frase se podía deducir que para que el principio democrático no fuera una mera "declaración retórica", los procesos de cambio o transformación constitucional no debían quedar reducidos a los que se preveían en la Constitución como norma suprema y fundamental. Pero si la Corte se atenía al otro principio del constitucionalismo moderno, el de la supremacía constitucional, es decir, el necesario respeto de la Constitución adoptada por el pueblo soberano que obliga y se impone por igual, como lo dijo la Corte, tanto a los gobernantes (poderes constituidos) como a los gobernados (poder constituyente), toda modificación de la voluntad popular plasmada en la Constitución sólo podía realizarse a través de los mecanismos de reforma o enmienda que establecía la misma Constitución que era, precisamente, obra de la soberanía popular. Sobre ello, sin embargo, la Corte Suprema dijo que "Si se estima que para preservar la soberanía popular, es al pueblo a quien corresponderá siempre, como titular del poder constituyente, realizar y aprobar cualquier modificación de la Constitución..., la que se verá corrosivamente afectada será la idea de supremacía”. Es decir, para que el principio de la supremacía constitucional no se viera corrosivamente afectado, las modificaciones a la Constitución sólo la podía realizar el pueblo a través de los mecanismos previstos en la propia Constitución.

Era claro, por tanto, cuál era el dilema abierto desde el punto de vista constitucional en ese momento histórico de Venezuela: o la soberanía popular era pura retórica si

13 Véase los comentarios sobre el dilema en Lolymar Hernández Camargo, La Teoría del Poder Constituyente. Un caso de estudio: el proceso constituyente venezolano de 1999, UCAT, San Cristóbal, 2000, pp. 53 y ss.; Claudia Nikken, La Cour Suprême de Justice et la Constitution vénézuélienne du 23 Janvier 1961. Thèse Docteur de l'Université Panthéon Assas, (Paris II), Paris, 2001, pp. 366 y ss. 
no podía manifestarse directamente fuera del marco de la Constitución; o la supremacía constitucional se veía corrosivamente afectada si se permitía que el pueblo soberano, como titular del poder constituyente, pudiera modificar la Constitución fuera de sus normas.

La solución del dilema podía ser relativamente fácil en una situación de hecho o de ruptura constitucional: el pueblo, como poder constituyente puede manifestarse siempre, particularmente porque al romperse el hilo constitucional no existe el principio de la supremacía constitucional. Ello sin embargo, no podía ocurrir en un proceso constituyente de derecho sometido a una Constitución, de manera que no estando Venezuela, a comienzos de 1999, en una situación de hecho, sino de vigencia del orden constitucional del texto de 1961, el dilema planteado entre soberanía popular y supremacía constitucional, frente a un proceso de cambio político incontenible como el que se estaba produciendo, no podía tener una solución que derivase de la sola discusión jurídica, sino que necesaria y básicamente tenía que tener una solución de carácter político, pero guiada por el órgano judicial del Estado constitucional, que podía interpretar la Constitución, es decir, la Corte Suprema de Justicia. Lo que era claro en ese momento es que en la discusión jurídica que se había abierto en el país para enfrentar el mismo dilema, habían quedado precisadas las dos posiciones indicadas:

Por una parte, la de quienes sostenían y sostuvimos que derivado del principio de la supremacía constitucional, en el Estado constitucional democrático de derecho representativo la Constitución establece los mecanismos para su revisión (reforma y enmienda), y al no regular a la Asamblea Constituyente como medio para la reforma, para que ésta pudiera convocarse debía previamente crearse y establecerse su régimen en el texto constitucional, mediante una reforma constitucional, que le diese status constitucional.

Por otra parte, la de quienes sostenían, encabezados por el Presidente de la República, que derivado del principio de que la soberanía reside en el pueblo como lo decía el artículo 4 de la Constitución de 1961, la consulta popular sobre la convocatoria y régimen de la Asamblea Constituyente, como manifestación de dicha soberanía popular declarada por el pueblo como poder constituyente originario mediante referendo, era suficiente para que la misma se convocara y eligiera, y acometiera la reforma constitucional sin necesidad de que previamente se efectuase una reforma constitucional para regularla. Se trataba, en definitiva, del debate sobre el poder constituyente en el Estado constitucional democrático representativo que intermitentemente ha dominado la discusión constitucional en todos los Estados modernos, y que siempre ha estado en la precisa frontera que existe entre los hechos y el derecho.

A la Sala Político Administrativa de la Corte Suprema de Justicia, como se ha dicho, se le había solicitado que interpretara en relación con la posibilidad de una consulta popular (referendo consultivo) sobre la convocatoria de la Asamblea Nacional Constituyente, si a través de un "referendo consultivo" como el establecido en el artículo 181 de la Ley Orgánica del Sufragio y de Partición Política "se puede determinar la 
existencia de voluntad popular para una futura reforma constitucional y, en caso afirmativo, si ese mecanismo legal de participación puede servir de fundamento a los efectos de convocar a una Asamblea Constituyente, de manera tal que se respete el ordenamiento constitucional vigente".

En las sentencias, la Corte Suprema después de realizar algunas citas doctrinales genéricas, precisó el dilema que tenía que resolver, así: "El asunto planteado es el dilema de si la propia Constitución, le es dado regular sus propios procesos de modificación y de reforma o si se considera que la soberanía corresponde directamente al pueblo, como titular del poder constituyente, reordenando al Estado. En el primer caso estaríamos en presencia del poder constituido. En el segundo, el poder constituyente tendría carácter absoluto e ilimitado". Después de disquisiciones como estas, la Corte Suprema terminó decidiendo que "la interpretación que debe atribuirse al artículo 181 de la Ley Orgánica del Sufragio y Participación Política, respecto del alcance del referendo consultivo que consagra, en cuanto se refiere al caso concreto objeto del recurso que encabeza las presentes actuaciones, es que: a través del mismo puede ser consultado el parecer del cuerpo electoral sobre cualquier decisión de especial trascendencia nacional distinto a los expresamente excluidos por la propia Ley Orgánica del Sufragio y Participación Política en su artículo 185, incluyendo la relativa a la convocatoria de una Asamblea Constituyente".

Es decir, la Corte Suprema de Justicia en esta sentencia, muy lamentablemente, no sólo no resolvió de manera expresa el dilema constitucional que se le había planteado y que ella misma había identificado, sino que se limitó sólo a decidir que conforme al artículo 181 de la Ley Orgánica del Sufragio y Participación Política, sí se podía realizar un referendo consultivo, para consultar el parecer del pueblo sobre la convocatoria de una Asamblea Constituyente; lo que nadie negaba, pues se trataba de una consulta popular sobre una materia de trascendencia nacional. Pero aparte de decidir lo anterior, sobre el otro asunto que se le había planteado a la Corte Suprema, que era el esencial desde el punto de vista constitucional, sobre si en definitiva, para convocar la Asamblea Constituyente bastaba el referendo consultivo o era necesario, además, reformar previamente la Constitución, la Corte nada resolvió ni decidió, y menos en forma precisa y clara.

En realidad, sobre este asunto, en las sentencias, la Sala llegó a la conclusión de que una vez efectuado un referendo consultivo conforme al artículo 181 de la Ley Orgánica del Sufragio y Participación Política, "aun cuando el resultado de la decisión popular adquiera vigencia inmediata, su eficacia sólo procedería cuando, mediante los mecanismos legales establecidos se dé cumplimiento a la modificación jurídica aprobada. Todo ello siguiendo procedimientos ordinarios previstos en el orden jurídico vigente, a través de los órganos del Poder Público competentes en cada caso. Dichos órganos estarán en la obligación de proceder en ese sentido".

De este párrafo lo que se deducía, en realidad, era que una consulta popular sobre la convocatoria a una Asamblea Constituyente no bastaba para efectivamente convocarla y 
reunirla, de manera que la consulta popular sólo podía interpretarse como un mandato político para que los órganos del Poder Público competentes pudieran proceder a efectuar las modificaciones jurídicas derivadas de la consulta popular, siguiendo los procedimientos ordinarios previstos en el orden jurídico vigente, tanto constitucional como legal. Sólo después de que estas modificaciones se efectuasen, conforme al criterio de la Corte, que no podían ser otras que no fueran las que resultasen de una revisión constitucional (reforma o enmienda), entonces era que la consulta popular podía ser efectiva. Ello implicaba que para efectuar la reforma e incorporar a la Constitución la figura de la Asamblea Constituyente, debía asegurarse la participación de los diputados y senadores y de las Cámaras Legislativas, con la participación del pueblo vía referendo aprobatorio conforme a los artículos 245 y 246 de la Constitución de 1961.

Es decir, lejos de decidir con precisión la cuestión constitucional planteada respecto de la posibilidad constitucional de la convocatoria de una Asamblea Constituyente sin una reforma previa de la Constitución, las sentencias de la Corte Suprema del 19 de enero de 1999, dentro de su imprecisión y ambigüedad, dejaron abierta la discusión constitucional, y con ello, la vía jurídico-judicial para la convocatoria de un referendo consultivo para que el pueblo se pronunciara sobre la convocatoria de una Asamblea Nacional Constituyente, sin que esta institución estuviese prevista en la Constitución de 1961 , vigente en ese momento, como un mecanismo de revisión constitucional. ${ }^{14}$ Con esta decisión, la Corte Suprema no sólo sentó las bases para el inicio del proceso constituyente venezolano de 1999, sino que dio comienzo al proceso que condujo al golpe de Estado perpetrado por la Asamblea Constituyente y, casi un año después, a que los nuevos titulares del Poder Público decretaran la extinción de la propia Corte Suprema que con su abstención había iniciado el proceso que les dio origen.

Como antes se dijo, la Corte Suprema no llegó a resolver lo esencial de la interpretación que le había sido requerida, y solo dijo que conforme a las normas sobre referendos de la Ley Orgánica del Sufragio y de Participación Política, se podía consultar al pueblo sobre la convocatoria de una Asamblea Constituyente, pero nada dijo sobre si para convocarla debía o no previamente reformarse la Constitución de 1961 para regularla en su texto. El resultado de esta ausencia de decisión de la Corte, sin embargo, en el momento político que vivía el país, en la práctica fue suplida por la "opinión pública" que se conformó por los titulares de primera página de los diarios nacionales de los días 20 de enero de 1999 y siguientes, los cuales fueron los que abrieron efectiva e insólitamente dicha vía hacia el proceso constituyente, al "informar" en grandes letras que, supuestamente, la Corte Suprema de Justicia había decidido que se podía proceder a convocar una Asamblea Nacional Constituyente para revisar la Constitución, sin necesidad de reformar previamente la Constitución de 1961, que la regulara. ${ }^{15}$ En ese momento, la euforia de los que de ello derivaron un "triunfo" jurídi-

14 Véase Jesús María Casal, "La apertura de la Constitución al proceso político”, en Constitución y Constitucionalismo Hoy, Fundación Manuel García-Pelayo, Caracas, 2000, pp. 127 y ss.

15 El Nacional, Caracas, 21-01-99, p. A-4 y D-1; El Universal, Caracas, 21-01-99, p. 1-2 y 1-3; El Universal, Caracas, 20-01-99, pp. 1-15. El titular de primera página del diario El Nacional del 20-01-99 rezó así: 
co, ${ }^{16}$ y la incredulidad y duda de otros, que no encontraban la "decisión" que anunciaba la prensa en el texto de la sentencia, impidieron precisar con exactitud el contenido de la misma. La verdad es que, como lo advertimos en su momento, ${ }^{17}$ eso no había sido lo que había decidido la Corte Suprema de Justicia en las sentencias de su Sala Político Administrativa del 19 de enero de 1999. Se insiste, la Corte debía decidir un recurso de interpretación de las normas de la Ley Orgánica del Sufragio y Participación Política sobre referendos, en el cual se le habían formulado dos preguntas muy precisas: primera, si se podía convocar un referendo relativo a una consulta popular sobre la convocatoria de una Asamblea Nacional Constituyente; y segunda, si se podía convocar dicha Asamblea para dictar una nueva Constitución, sin que se reformase previamente la Constitución de 1961, la cual no preveía la existencia de dicha Asamblea. La Corte, como ya lo hemos analizado anteriormente, resolvió claramente sólo la primera pregunta, y simplemente no se pronunció sobre la segunda. La sentencia se limitó a señalar que para realizar un referendo sobre el tema de la Constituyente no era necesario reformar previamente la Constitución; pero la Sala no se pronunció sobre si luego de efectuada la consulta popular, debía o no reformarse la Constitución de 1961 para poder convocar efectivamente la Asamblea Nacional Constituyente que no estaba regulada en norma alguna, como mecanismo para la revisión constitucional, precisamente para regularla en la Constitución como uno de dichos mecanismos.

El resultado final de esta carencia, y la opinión pública construida de ella, buscándose evitar el conflicto constitucional, desviaron la discusión jurídica constitucional hacia otros aspectos, siendo el resultado final la convocatoria del referendo consultivo sobre la Asamblea Nacional Constituyente que se efectuó en abril de 1999, la elección de la misma en julio de 1999, y la subsiguiente asunción del "poder constituyente originario" por la Asamblea a partir de agosto de 1999, con lo cual intervino todos los

“CSJ, considera procedente realizar un referéndum para convocar la Constituyente"; el titular del cuerpo de Política del mismo diario, del 21-01-99, rezó así: "No es necesario reformar la Constitución para convocar el referéndum” y el del día 22-01-99 rezó así: "La Corte Suprema no alberga dudas sobre la viabilidad de la Constituyente". Véanse los comentarios coincidentes de Lolymar Hernández CAMARGO, La Teoría del Poder Constituyente, cit., p. 63.

16 Ello se deducía de la propia Exposición de Motivos del Decreto $\mathrm{N}^{\circ} 3$ del 02-02-99 del Presidente de la República convocando al referendo consultivo sobre la Asamblea Nacional Constituyente en la se dijo que: "b) La Corte Suprema de Justicia, en sus decisiones del 19 de enero de 1999, ha establecido que para realizar el cambio que el país exige, es el Poder Constituyente, como poder soberano previo y total, el que puede, en todo momento, modificar y transformar el ordenamiento constitucional, de acuerdo con el principio de la soberanía popular consagrado en el artículo 4 de la Carta Fundamental; c) El referendo previsto en la Ley Orgánica del Sufragio y Participación Política, es un mecanismo democrático a través del cual se manifiesta el poder originario del pueblo para convocar una Asamblea Nacional Constituyente y un derecho inherente a la persona humana no enumerado, cuyo ejercicio se fundamenta en el artículo 50 del Texto Fundamental y que, ese derecho de participación, se aplica no sólo durante elecciones periódicas y de manera permanente a través del funcionamiento de las instituciones representativas, sino también en momentos de transformación institucional que marcan la vida de la Nación y la historia de la sociedad". (Gaceta Oficial N 36.634 de 02-02-99).

17 Véase Allan R. Brewer-Carías, Poder Constituyente Originario y Asamblea Nacional Constituyente, Fundación de Derecho Público, Caracas 1999, pp. 66 y ss. Véase además, lo expuesto en Allan R. BREWERCARÍAS, Golpe de Estado y proceso constituyente en Venezuela, UNAM, México, 2002, pp. 85 y ss. 
poderes constituidos, entre ellos el Poder Judicial, disolviendo el Congreso y finalmente a la propia Corte Suprema, dando, en fin, un golpe de Estado.

\section{LA PROPUESTA DEL PRESIDENTE DE LA REPÚBLICA DE HONDURAS EN 2009, PARA LA REALIZACIÓN DE UNA CONSULTA POPULAR SOBRE LA CONVOCATORIA DE UNA ASAMBLEA NACIONAL CONSTITUYENTE Y SU SUSPENSIÓN POR LA JURISDICCIÓN CONTENCIOSO ADMINISTRATIVA}

El precedente venezolano de convocatoria de un referendo consultivo sobre la convocatoria de una Asamblea Nacional Constituyente no prevista en la Constitución, para reformarla, se siguió a la letra en 2007 por el presidente Rafael Correa en Ecuador, donde se recurrió a la misma fórmula, haciéndose prevalecer la expresión de la voluntad popular mediante una simple consulta, aún manifestada sin asidero constitucional, conduciendo a la Asamblea Constituyente a la asunción del Poder total del Estado, salvo el del Presidente de la República, no sólo para redactar una nueva Constitución sino para intervenir y controlar todos los otros poderes del Estado. ${ }^{18}$ En Ecuador, sin embargo, no hubo intervención judicial para dilucidar la convocatoria a la Asamblea Constituyente no prevista en la Constitución, habiéndose quedado los conflictos constitucionales, básicamente, entre el Congreso y el Tribunal Electoral.

En todo caso, la modalidad de la convocatoria de una consulta popular para obtener la opinión del pueblo sobre la convocatoria de una Asamblea Nacional Constituyente no prevista en la Constitución como mecanismo de reforma constitucional, para con base en la expresión popular poder convocarla, forzando la prevalencia de la soberanía popular sobre la supremacía constitucional, fue también lo que quiso imponer en Honduras el Presidente José Manuel Zelaya en 2009, con la diferencia de que en este país, los tribunales de la jurisdicción contencioso administrativa efectivamente asumieron su función, y funcionaron y decidieron como contralores de la constitucionalidad y legalidad de las actuaciones del Presidente de la República, llegando a suspender los efectos de los actos ejecutivos dictados en la materia. ${ }^{19}$

1. El Decreto Ejecutivo $N^{\circ}$ PCM-05-2009, de marzo de 2009, convocando a una consulta popular sobre una Asamblea Nacional Constituyente y su impugnación en vía contencioso administrativa

18 Véase lo expresado sobre este proceso en Allan R. BREWER-CARÍAs, "El inicio del proceso constituyente en Ecuador en 2007 y las lecciones de la experiencia venezolana de 1999”, texto de la Videoconferencia dada el 19 de abril de 2007 desde la Universidad de Columbia, Nueva York, al Programa de Postgrados de Jurisprudencia, Universidad San Francisco de Quito, 19 abril 2007. Véase en www.allanbrewercarias.com, Sección I, 1, 949 (2007).

19 Para la narración de los hechos y actos estatales adoptados en este caso, así como las diversas decisiones y actuaciones judiciales realizadas por la Jurisdicción contencioso administrativa y la Corte Suprema de Honduras, hemos partido exclusivamente, del estudio del contenido de las copias de las actas procesales respectivas. Véase Expediente Zelaya, Documentos, El Nacional, Caracas. 
En efecto, el 24 de marzo del 2009, en cadena televisiva y de radio, el Presidente de Honduras anunció que en Consejo de Ministros del día anterior ( 23 de marzo de 2009), se había emitido un Decreto Ejecutivo N PCM-05-2009, en el cual se había ordenado realizar una "amplia consulta popular" para que la ciudadanía hondureña pudiera expresar libremente su acuerdo o no con la convocatoria a una Asamblea Nacional Constituyente, a los efectos de dictar y aprobar una nueva constitución política, disponiendo que el ente que estaría a cargo de la ejecución del Decreto sería el Instituto Nacional de Estadística (INE), previendo la realización de la consulta para el último domingo del mes de junio del 2009.

El texto de la consulta popular que el Presidente de la República proponía, en lo que en definitiva era un "referendo consultivo", consistía en la siguiente pregunta:

“¿Está usted de acuerdo que en las elecciones generales del 2009, se instale una cuarta urna para decidir sobre la convocatoria a una Asamblea Nacional Constituyente que apruebe una nueva Constitución Política?"

Este Decreto $\mathrm{N}^{\circ} \mathrm{PCM}-005-2009$, según se afirmó en el primer "Considerando" del Decreto $\mathrm{N}^{\circ}$ PCM-019-2009 de fecha 26 de mayo de 2009, nunca se llegó a publicar por el Poder Ejecutivo en el Diario Oficial, "por razones de mérito y oportunidad". Por ello se lo consideró como un acto administrativo tácito de carácter general emitido por el Poder Ejecutivo que había sido ampliamente publicitado, aun cuando no formalmente publicado en el Diario Oficial, que es el requisito para que cualquier acto de efectos generales pueda producir efectos (artículo 255 de la Constitución y artículo 32 de la Ley de Procedimiento Administrativo).

En todo caso, en virtud de que la publicitada propuesta presidencial se apartaba de lo que la Constitución de Honduras establecía en materia de reforma constitucional, el 8 de mayo de 2009, dos fiscales del Ministerio Público, órgano constitucional al cual corresponde ser garante de la Constitución, presentaron ante el Juzgado de Letras de lo Contencioso Administrativo de Tegucigalpa (Municipio del Distrito Central), una demanda ordinaria contencioso administrativa "contra el Estado de Honduras", de declaratoria de ilegalidad y la nulidad del "acto administrativo tácito de carácter general emitido por el Poder Ejecutivo" y que estaba contenido en el mencionado Decreto Ejecutivo $\mathrm{N}^{\circ}$ PCM-05-2009, por considerar que el mismo no estaba ajustado a derecho.

Los Fiscales solicitaron además, ante el mismo Juzgado contencioso administrativo, como medida cautelar, que suspendiera los efectos del acto impugnado.

En el proceso (Orden de ingreso $N^{\circ}$ 151-2009), el Estado de Honduras estuvo representado por la Procuradora General de la República, quien actuó en el proceso.

2. La suspensión de efectos del Decreto Ejecutivo $N^{\circ}$ PCM-05-2009, de 23 de marzo de 2009 decretada por el juez contencioso administrativo 
El artículo 121 de la Ley de la Jurisdicción de lo Contencioso Administrativo prescribe que procede la suspensión de efectos de los actos administrativos impugnados en vía contencioso administrativa, cuando "la ejecución hubiere de ocasionar daños o perjuicios de reparación imposible o difícil”, por lo que con base en dicha norma, en el libelo de la demanda que originó el juicio, la parte demandante, es decir, el Ministerio Público, solicitó ante el Juez contencioso administrativo que dictase una medida cautelar incidental de suspensión de los efectos del acto administrativo impugnado, lo que efectivamente fue decidido por el Juzgado el 27 de mayo de 2009 mediante sentencia interlocutoria de suspensión del acto impugnado (es decir, del Decreto presidencial $\mathrm{N}^{\circ}$ PCM-05-2009 de 23 de marzo de 2009).

Para dictar dicha sentencia interlocutoria, el Juez contencioso administrativo apreció la solicitud del Ministerio Público que se fundamentaba en la consideración de que el acto administrativo impugnado era "de gran impacto que ocasionaría daños y perjuicios de reparación imposible al sistema democrático del país en franca violación a la Constitución de la República y demás leyes, así como perjuicios económicos, por ejecutar acciones de la dimensión de una consulta a nivel nacional, y por perjuicios graves a la sociedad de difícil reparación a todas las instituciones del poder ejecutivo, y se prohíba a todas las empresas privadas que estén ejerciendo contratos para la ejecución del decreto".

Y además, en su sentencia el Juez agregó que la parte demandada, es decir, el Estado de Honduras representado por la Procuradora General de la República, al devolver la vista, había reconocido que el Juzgado tenía la potestad de suspender actos administrativos, y había indicado que el acto impugnado, de ser ciertas las imputaciones sobre el mismo, "constituye grave infracción al ordenamiento jurídico, que lesiona intereses del Estado de Honduras y de la generalidad del pueblo hondureño, ocasionando un daño al Estado de Honduras de reparación imposible, asî como de las erogaciones económicas ya que el poder ejecutivo ha publicitado por medios de comunicación privados para el cometido del acto administrativo impugnado, y que generan gastos cuantiosos para la administración pública, los que tienden a incrementarse cada día”. Es decir, ambas partes en el proceso contencioso administrativo, representantes de instituciones fundamentales del Estado, estuvieron contestes con los poderes del juez contencioso administrativo sobre la suspensión de los efectos del acto impugnado, y con que dicho Juez, de acuerdo con la Ley de la Jurisdicción, emitiera la sentencia que correspondiera.

Por su parte, el Juez Titular del Juzgado contencioso administrativo para decidir la incidencia de suspensión de efectos del Decreto presidencial impugnado, consideró que cuando se resuelven solicitudes de esta naturaleza, "se ha de tomar en consideración que la tutela judicial no será efectiva, si al pronunciarse la sentencia definitiva, resulta difícil o prácticamente imposible la satisfacción de la pretensión contenida en la demanda", considerando entonces que la correcta decisión de solicitud que se le había formulado, exigía conforme a la más clásica técnica judicial en materia de medidas cautelares: 
"la ponderación y armonización de dos principios en pugna, por un lado, el de la efectiva tutela judicial, y, por otro, el de la eficacia de la acción administrativa, esto por la presunción de legitimidad del acto impugnado, principios que buscan evitar que con la ejecución del acto impugnado se causen perjuicios de difícil o imposible reparación, de no decretarse la suspensión del acto que se impugna, por lo que al decretar la suspensión de los efectos de un determinado acto impugnado lo que se busca es prever que al momento de emitirse un fallo definitivo sea meramente declarativo e ineficaz con respecto a las pretensiones del demandante".

Con base en lo anterior, el Juez en su sentencia interlocutoria de suspensión, teniendo en cuenta que ambas partes en el proceso habían estado contestes sobre sus facultades legales en materia contencioso administrativa para decidir sobre la revisión, suspensión y nulidad de actos administrativos; y considerando "que El Estado de Honduras es un Estado de Derecho, por lo que sus actuaciones están sometidas únicamente al imperio de la Constitución de la República y las leyes", decidió que era "procedente decretar la suspensión del acto administrativo tácito objeto de revisión en el presente juicio por considerar que su implementación redundaría en daños de carácter económico, político y sociales que serían de imposible reparación para el Estado de Honduras". Esa decisión la adoptó el Juez contencioso administrativo en aplicación de los artículos 5, 80, 82, 90, 245, 303, 304 y 305 de la Constitución de la República; artículos 1,11, 40 y 137 de la Ley de Organización y Atribuciones de los Tribunales; artículos 1,2; 3, 7, 13 letra b), 101, 120, 121, 122, 125, 129, 132 y 134 de la Ley de la Jurisdicción de lo Contencioso Administrativo; artículos 130, 131, 134, 138, 141 y 142 del Código de Procedimientos Civiles; y artículos 9, 15 y 16 de la Ley del Ministerio Público; y además, en aplicación del Oficio número SCSJ-3623-88 y Acuerdo número 03-98 de la Honorable Corte Suprema de Justicia.

La consecuencia de declarar con lugar la cuestión incidental de suspensión de los efectos del acto impugnado, que era el acto administrativo tácito de carácter general impugnado contenido en el Decreto Ejecutivo $\mathrm{N}^{\circ}$ PCM-05-2009 del 23 de marzo del 2009, tal como lo habían solicitado los Fiscales del Ministerio Público demandantes, fue además, la orden judicial de suspensión de "cualquier tipo de publicidad sobre lo establecido en el mismo" y, en general, "del procedimiento de consulta a los ciudadanos por parte del Poder Ejecutivo a través del Presidente Constitucional de la República, o cualquiera de las instituciones que componen la estructura administrativa del Poder Ejecutivo".

Por tanto, el objetivo de la decisión cautelar de suspensión de efectos del acto administrativo impugnado fue el que el Presidente de la República y, en general, todos los órganos del Poder Ejecutivo se abstuvieran de realizar actividad alguna relativa a la propuesta presidencial de consulta popular a los ciudadanos sobre el tema de una Asamblea Nacional Constituyente no prevista en la Constitución. Para asegurar el cumplimiento de la sentencia, el Juez en su decisión, mandó notificarla "al Señor Presidente Constitucional de la República a través del Señor Secretario de Estado en el Despacho Presidencial, para su conocimiento y cumplimiento inmediato, haciéndole 
las prevenciones establecidas en el artículo 101 de la Ley de la Jurisdicción de lo Contencioso Administrativo de no cumplir la misma".

3. La "reedición" del acto administrativo impugnado mediante Decreto Ejecutivo $N^{\circ}$ PCM-19-2009, de mayo de 2009, convocando a una "encuesta nacional de opinión" sobre una Asamblea Nacional Constituyente

La anterior decisión del Juez contencioso administrativa, como se dijo, fue dictada el día 27 de mayo de 2009 suspendiendo los efectos del acto administrativo tácito contendido en el Decreto ejecutivo N PCM-05-2009 de 24 de marzo de 2009 (nunca publicado), que ordenaba la realización de una consulta popular no autorizada en la Constitución.

Sin embargo, y quizás sabiendo el Presidente de la República que la decisión del Tribunal Contencioso Administrativo iba a ser dictada suspendiendo los efectos de su PCM-05-2009 de 23 de marzo de 2009, el cual como se dijo nunca fue publicado en Gaceta Oficial "por razones de mérito y oportunidad” (es decir, deliberadamente); el día anterior a la sentencia, es decir, el 26 de mayo de 2009, el Presidente de la República en Consejo de Ministros emitió un "nuevo" Decreto Ejecutivo N ${ }^{\circ}$ PCM-19-2009, el cual tampoco fue publicado en el Diario Oficial La Gaceta sino un mes después, es decir, el día 25 de junio de 2009 ( $\mathrm{N}^{\circ}$ 31.945), mediante el cual se decidió anular y dejar "sin ningún valor y efecto" el Decreto PCM-05-2009 que ordenaba una consulta popular, a partir de su emisión; y que como se dijo había sido el acto impugnado y cuya suspensión de efectos era inminente. Ello, por supuesto era contradictorio: si un acto no publicado en el Diario Oficial como lo decía uno de los Considerandos del decreto no surtía efectos, no parecía lógico que en el mismo decreto se resolviese "dejar sin efectos" un acto que supuestamente no había surtido efectos.

En todo caso, en lugar del Decreto de 23 de marzo de 2009 que se revocaba y, en concreto en lugar de la "consulta popular" que entonces se había ordenado, mediante un nuevo Decreto N $^{\circ}$ PCM-20-2009 dictado el mismo día 26 de mayo de 2009 (publicado también un mes después en el Diario Oficial La Gaceta $N^{\circ} 31.945$ del 25 de junio de 2009), el Presidente había dispuesto que se realizase, no una consulta popular, sino "una encuesta nacional de opinión", que se debía llevar a cabo el 28 de junio de 1999 , en la cual debía formularse una pregunta similar en su forma a la antes propuesta para la "consulta popular, pero sustancialmente distinta, de si:

“¿Está usted de acuerdo que en las elecciones generales del 2009, se instale una cuarta urna en la cual el pueblo decida la convocatoria a una Asamblea Nacional Constituyente? Sí No

En el nuevo Decreto, que se calificó como "de ejecución inmediata" aun cuando debía publicarse en el Diario Oficial (artículo 5), además, se instruía "a todas las dependencias y órganos de la Administración pública, Secretarías de Estado, Instituciones Descentralizadas y Desconcentradas, para que se incorporasen y ejecutasen activa- 
mente, "todas las tareas que le sean asignadas para la realización del proyecto denominado «Encuesta de Opinión Pública convocatoria Asamblea Nacional Constituyente», considerando que según el referido Decreto, ello constituía, "una actividad oficial del Gobierno".

La diferencia era notoria: antes lo que se buscaba era que el pueblo, con una respuesta afirmativa a la pregunta de la "consulta popular", decidiera "sobre la convocatoria a una Asamblea Nacional Constituyente que apruebe una nueva Constitución Política”; ahora lo que se buscaba era que el pueblo con una respuesta afirmativa a la pregunta de una "encuesta nacional de opinión", decidiera "la convocatoria a una Asamblea Nacional Constituyente". El efecto de la manifestación popular era, por tanto, radicalmente distinto, y lo que aparentemente era una propuesta para una "consulta popular" y luego para una "encuesta de opinión", se había convertido en una propuesta para un referendo decisorio tendiente a lograr una "decisión” popular al margen de la Constitución. Tal como ocurrió en Venezuela en febrero de 1999, cuando el Presidente de la República, utilizando la vía de un "referendo consultivo" previsto en una ley, propuso la formulación de una pregunta que era más bien la de un referendo decisorio no previsto en ley alguna, con el cual se pretendía modificar la Constitución. ${ }^{20}$

El nuevo Decreto $\mathrm{N}^{\circ} \mathrm{PCM}-20-2009$, por otra parte, contenía una extensa motivación entre otros, en los artículos 2 y 5,1 de la Constitución, en los cuales se dispone que la soberanía corresponde al pueblo del cual emanan todos los Poderes del Estado, agregando que "el Gobierno debe sustentarse en el principio de la democracia participativa del cual se deriva la integración nacional, que implica participación de todos los sectores políticos en la administración pública, a fin de asegurar y fortalecer el progreso de Honduras basado en la estabilidad política y en la coalición nacional”. En los considerandos del Decreto se afirmaba igualmente que "la sociedad hondureña ha experimentado cambios sustanciales y significativos en los últimos veintisiete años, cambios que demandan un nuevo marco constitucional para adecuarlo a la realidad nacional, como una legítima aspiración de la sociedad". Por último, en el decreto se afirmó que había sido en virtud de diversas solicitudes de ciudadanos en forma individual o por medio de sectores y grupos sociales organizados del país, que el Poder Ejecutivo, había "decidido convocar a la ciudadanía en general para que emita su opinión y formule propuestas de solución a problemas colectivos que les afecte; como ser la instalación de una cuarta urna que permita un eficaz ejercicio de su derecho".

Dos días después de este Decreto N$^{\circ}$ PCM-19-2009, en fecha 29 de mayo del 2009, el Presidente de la República, mediante cadena nacional informó al pueblo Hondureño a través del entonces Secretario de Estado en el Despacho de la Defensa Nacional, Dr. Edmundo Orellana Mercado, que el Presidente constitucional en Consejo de Ministros, había aprobado otro acuerdo ejecutivo $\mathrm{N}^{\circ}$ 027-2009, en el cual se ordenaba se llevase a la práctica una "encuesta nacional de opinión", bajo la responsabili-

20 Véase en Allan R. Brewer-Carías, Asamblea Constituyente y Ordenamiento..., cit., pp.180 ss. 
dad del Instituto Nacional de Estadística (INE), y en este, se ordenaba a las Fuerzas Armadas de Honduras, que apoyasen con sus medios logísticos y demás recursos necesarios al Instituto Nacional de Estadística (INE), estableciendo que dicho acuerdo ejecutivo entraba en vigencia a partir de su fecha (29/05/09).

Estos Decretos, son de los que en el derecho administrativo se conocen como "reedición" de los actos administrativos dictados después de que han sido impugnados en vía contencioso administrativa y, en este caso, en la víspera de que se suspendieran judicialmente sus efectos, por otros actos administrativos que en definitiva perseguían objetivos similares, lo que está proscrito en materia contencioso administrativa, pues constituye una burla a los poderes de control de la jurisdicción.

4. La aclaratoria de la sentencia del Juez contencioso administrativo de suspensión de efectos del Decreto presidencial impugnado

El mismo día del anuncio presidencial del decreto $\mathrm{N}^{\circ}$ PCM-27-2009, el 29 de mayo de 2009, los abogados del Ministerio Público que actuaban como parte demandante en el proceso contencioso administrativo (parte incidentista) solicitaron aclaratoria de la sentencia interlocutoria de suspensión de efectos que se había dictado, y el Juez Titular, al constatar sus propios poderes como los de todos los jueces de la Jurisdicción contencioso administrativa para adoptar "cuantas medidas sean necesarias para satisfacer totalmente lo resuelto en los fallos que emitan, esto, a fin de asegurar el estricto cumplimiento de lo ordenado en los mismos, para la ejecución de la tutela judicial efectiva, y no se evadan a través de otros actos administrativos, las disposiciones contenidas en sus fallos", consideró "que de haberse emitido, o de emitirse acto administrativo que contravenga o venga a contravenir lo dispuesto en la sentencia interlocutoria de fecha 27 de mayo del 2009, sería para evadir lo ordenado en la misma, así como el mandato judicial mismo, por lo que cualquier decisión administrativa dictada en este sentido es improcedente, por no poder evadirse el mandamiento judicial a través de actos administrativos". Como consecuencia, resolvió aclarar en sentencia de 29 de mayo de 2009, que

“La Sentencia Interlocutoria de fecha 27 de mayo del 2009 en el sentido que los efectos de la suspensión ordenada, del acto tácito de carácter general que contiene el Decreto Ejecutivo número PCM-05-2009 de fecha 23 de marzo del 2009, incluye a cualquier otro acto administrativo de carácter general o particular, que se haya emitido o se emita, ya sea expreso o tácito, por su publicación o falta de publicación en el Diario Oficial La Gaceta, que conlleve al mismo fin del acto administrativo tácito de carácter general que ha sido suspendido, así como cualquier cambio de denominación en el procedimiento de consulta o interrogatorio, que implique evadir el cumplimiento de la sentencia interlocutoria que se aclara”.

Es decir, el juez contencioso administrativo censuró, conforme a lo previsto en los artículos 82, 84, 132 y 134 de la Ley de la Jurisdicción de lo Contencioso Administrativo; y en el artículo 195 del Código de Procedimientos Civiles, cualquier tipo de "reedición" o novación administrativa que pudiera permitir burlar los efectos de la decisión judicial de suspensión de efectos de la "consulta popular" que había sido 
ordenada por el Presidente de la República, cualquiera que fuese la "forma" que se le pretendiera dar.

5. La inadmisibilidad de la acción de amparo intentada por el Presidente de la República contra la decisión del Juez contencioso administrativo suspendiendo los efectos de sus decretos sobre la convocatoria de una Constituyente

Contra las decisiones del Juzgado de Letras de lo Contencioso Administrativo, es decir, contra la sentencia interlocutoria de 27 de mayo de 2009 y su aclaración de 29 de mayo de 2009, que declaró con lugar la cuestión incidental de suspensión de efectos del Decreto Ejecutivo impugnado, y prohibió cualquier tipo de publicidad sobre el procedimiento de consulta a los ciudadanos por parte del Poder Ejecutivo que comprometa la estructura administrativa del Poder Ejecutivo y cualquier otro que se emita aunque cambie de denominación, el Presidente Constitucional de la República en su condición de Titular del Poder Ejecutivo, representado por un abogado, intentó acción de amparo por ante la Corte de Apelaciones de lo Contencioso Administrativo en Tegucigalpa.

Esta Corte, en sentencia de 16 de junio de 2009, consideró que siendo el proceso contencioso administrativo desarrollado ante el Juzgado de Letras, un proceso en el cual las partes eran el Ministerio Público como demandante, y el Estado de Honduras como demandado, la acción de amparo que pudiera intentarse contra las decisiones dictadas en el proceso sólo podían ser interpuestas por las partes interesadas en el mismo; de lo que concluyó resolviendo que "siendo el demandado, el Estado de Honduras, resulta obvio que quien interpone el amparo carece de legitimación para ejercer la presente acción, puesto que constitucionalmente el representante legal del Estado es la Procuraduría General de la República, quien no ha interpuesto recurso alguno y por ende ha consentido la sentencia y la aclaración recurrida". De ello concluyó la Corte de Apelaciones que en el caso sometido a su consideración, la acción de amparo intentada resultaba inadmisible, lo que ocurre "cuando los actos hayan sido consentidos por el agraviado y se entenderán que han sido consentidos por el agraviado, cuando no se hubieren ejercitado, dentro de los términos legales, los recursos o acciones"; resolviendo entonces, en nombre del Estado de Honduras, rechazar de plano la demanda de amparo por considerarla inadmisible, en aplicación de los artículos 183, 228, 303, 304, 321, 322 y 323 de la Constitución de la República; 41 , 44, 46 numeral 3 y párrafo último de la Ley Sobre la Justicia Constitucional.

6. La conminación judicial al Presidente de la República para que acatara las decisiones de la Jurisdicción contencioso administrativa

A los efectos de dar cumplimiento a la sentencia interlocutoria antes referida, en fecha 3 de junio de 2009, el Juzgado de Letras de la Jurisdicción de lo Contencioso Administrativo, libró una primera comunicación judicial dirigida al Presidente de la República, a través del Secretario de Estado en el Despacho de la Presidencia, para que adoptase las medidas que procedieran y practicase lo exigido en cumplimiento de la sentencia interlocutoria dictada. 
Posteriormente, uno de los abogados del Ministerio Público, con fecha 18 de junio de 2009, solicitó al Juzgado de Letras Contencioso Administrativo, que nuevamente librara comunicaciones judiciales dirigidas al Presidente de la República y al secretario de Estado de la Presidencia, a efecto de que informasen ante el Juzgado sobre las medidas que hubiesen adoptado para dar estricto cumplimiento a la sentencia interlocutoria de 27 de mayo de 2009 y su aclaratoria de fecha 29 de mayo de 2009 , y asimismo para que se abstuviesen de realizar actos de carácter general o particular distintos a lo ordenado en la antes mencionada sentencia interlocutoria y su respectiva aclaratoria.

Acorde con ello, el Juez titular del Juzgado de Letras de lo Contencioso Administrativo, en la misma fecha 18 de junio de 2009, libró sendas comunicaciones judiciales dirigidas al Presidente de la República y al Secretario de Estado en el Despacho de la Presidencia, requiriéndoles que informasen sobre las medidas que hubiesen adoptado para dar estricto cumplimiento a la sentencia interlocutoria antes mencionada, y para que se abstuviesen de realizar actos generales y particulares contrarios a la misma, "haciéndole la advertencia que de verificarse el incumplimiento de la sentencia interlocutoria y su respectiva aclaratoria antes mencionadas, se le hace la advertencia de lo establecido en el artículo 349 del Código Penal, sin perjuicio de la responsabilidad civil en que incurriere por los daños y perjuicios que causare a los interesados; asimismo, de infringir lo dispuesto en la sentencia interlocutoria y su respectiva aclaratoria antes mencionadas, este Juzgado le aplicará multa que se hará efectiva mediante el procedimiento de apremio, la que no podrá ser menor de quinientos lempiras (Lps. 500.00), ni mayor de cinco mil lempiras (Lps. 5,000.00)". El informe que se solicitaba, conforme a las notificaciones judiciales, debía ser rendido "bajo su personal y directa responsabilidad ante este Juzgado en el plazo máximo e improrrogable de cinco (5) días hábiles siguientes a recibida la presente, comunicación, advirtiéndole que de no hacerlo así en el plazo señalado, este Juzgado le impondrá multa por cantidad no inferior a los doscientos lempiras (Lps. 200.00), ni superior a los dos mil lempiras (Lps. 2,000.00)”.

Luego, el mismo día 18 de junio de 2009, el Juez libró una tercera comunicación judicial dirigida al Presidente de la República, a través de la Secretaría General del Despacho Presidencial, a fin que dentro del plazo de cinco (5) días, informara al órgano jurisdiccional qué medidas había adoptado para dar cumplimiento a la sentencia interlocutoria y su respectiva aclaración.

Ninguna de las comunicaciones anteriores fuer respondida por el Presidente de la República ni por funcionario alguno del Poder Ejecutivo.

\section{EL DESACATO PRESIDENCIAL A LAS DECISIONES DE LA JURISDICCIÓN CONTENCIOSO ADMINISTRATIVA Y SUS CONSECUENCIAS}

A pesar de las precisas órdenes judiciales emanadas del Juzgado de lo contencioso administrativo, que prohibían al Presidente de la República realizar actos generales y particulares contrarios a la decisión de suspensión de efectos del Decreto presidencial 
sobre la consulta popular sobre la Asamblea Constituyente, éste continuó con su proyecto de realizar la "encuesta de opinión" prohibida judicialmente.

1. El desacato presidencial a cumplir las órdenes judiciales y el decomiso del material destinado a la realización de la encuesta de opinión

El Juzgado de Letras Contencioso Administrativo, en atención al requerimiento formulado por el Fiscal General de la República en el cual denunció el desacato por parte del Poder Ejecutivo de las órdenes judiciales, con fecha 26 de junio de 2009 dictó una nueva decisión judicial ordenando a las Fuerzas Armadas de Honduras, por medio del Jefe del Estado Mayor Conjunto, "el inmediato decomiso de toda la documentación y material necesario y relacionado con la encuesta de opinión que el Poder Ejecutivo, en abierta violación a la orden emanada de este Juzgado, pretende realizar el día domingo 28 de junio de dos mil nueve".

Para adoptar esta decisión judicial, el Juez se había previamente dirigido al Jefe del Estado Mayor Conjunto de las Fuerzas Armadas de Honduras solicitándole información sobre el cumplimiento de lo ordenado por el Juzgado, a lo que las Fuerzas Armadas habían respondido el 24 de junio de 2009, informándole "que han acatado lo ordenado en la misma”.

La decisión judicial de decomiso antes indicada se adoptó luego de que el Juez expresara, primero, que en virtud de la decisión judicial de fecha 27 de mayo de 2009, se había ordenado la suspensión de "toda actividad tendiente a realizar cualquier tipo de consulta o encuesta de opinión con el objetivo de instalar una cuarta urna en las elecciones generales de noviembre próximo para convocar a una Asamblea Nacional Constituyente; lo que conlleva inexorablemente la derogatoria de la Constitución de la República"; segundo, "con el objeto de dar cumplimiento a la suspensión decretada mediante el fallo supraindicado se libraron las correspondientes comunicaciones judiciales a efecto de dar conocimiento a distintas instituciones, entre ellas la Presidencia de la República, a que se abstuviesen de continuar realizando actividades orientadas a la realización de cualquier consulta o encuesta de opinión"; y tercero, "que a pesar de lo anterior, el Poder Ejecutivo, en pleno desconocimiento del fallo judicial, ha continuado con el intento de realizar la encuesta de opinión programada para el próximo domingo 28 de los corrientes".

El Juez contencioso administrativo para ordenar el decomiso de toda la documentación y material necesario y relacionado con la encuesta de opinión que el Poder Ejecutivo pretendía realizar "en abierta violación a la orden emanada de este Juzgado”, partió de lo dispuesto en el artículo 304 de la Constitución, que atribuye a los "órganos jurisdiccionales aplicar las leyes a casos concretos; juzgar y ejecutar lo juzgado". Consideró, además, que conforme a la previsión del artículo 274 de la Constitución, las Fuerzas Armadas "están sujetas a las disposiciones de su Ley Constitutiva y a las demás leyes y reglamentos que regulen su funcionamiento”, y conforme al artículo 1 de la Ley Constitutiva de las Fuerzas Armadas, estas se instituyen para, entre otras 
cosas, "defender el imperio de la Constitución". Con base en lo anterior; consideró que "siendo que la celebración de la Encuesta de Opinión tiene como propósito final mancillar la Constitución de la República; las Fuerzas Armadas de Honduras, en apego a las disposiciones anteriormente relacionadas, son la institución llamada a su defensa evitando la consumación de tal propósito", resolviendo de acuerdo con los artículos 272, 304 y 274 de la Constitución de la República; 1, 132 y de la Ley de la Jurisdicción Contencioso Administrativo; 1 de la Ley Constitutiva de las Fuerzas Armadas,

PRIMERO: Ordenar a las Fuerzas Armadas de Honduras, por medio del Jefe del Estado Mayor Conjunto, el inmediato decomiso de toda la documentación y material necesario y relacionado con la encuesta de opinión que el poder ejecutivo, en abierta violación a la orden emanada de este juzgado, pretende realizar el día domingo 28 de junio de dos mil nueve. Asimismo se le ordena a las Fuerzas Armadas de Honduras, que dichos documentos y material relacionado, por constituir una amenaza flagrante a la Constitución de la República, sea incinerado de forma inmediata.

A los efectos de que se realizase la medida ordenada, el Juez habilitó todos los días y horas inhábiles, bajo la coordinación técnica y legal de la Fiscalía General de la República; exigiéndose a todos los funcionarios y empleados de las diferentes Secretarías de Estado, entes descentralizados y desconcentrados, brindar toda la colaboración necesaria a fin de que las Fuerzas Armadas de Honduras pudiesen realizar de forma oportuna y eficiente el decomiso del material destinado a ser usado en la Encuesta de Opinión mencionada. A tal efecto, además, el juez facultó a las Fuerzas Armadas de Honduras, con el propósito del efectivo cumplimiento de lo ordenado, a utilizar los bienes e instalaciones de las instituciones del Estado, que considerase necesarias, en especial, las telecomunicaciones".

2. La destitución del Jefe del Estado Mayor Conjunto de las Fuerzas Armadas por el Presidente de la República, por cumplir lo ordenado por la Jurisdicción Contencioso Administrativa, y la suspensión de sus efectos del acto de destitución por la Sala Constitucional de la Corte Suprema

El mismo día 24 de junio de 2009, al acatar el Jefe del Estado Mayor Conjunto de las Fuerzas Armadas y proceder a decomisar el material destinado a la realización de la encuesta de opinión prohibida por el Juez contencioso administrativa, que se consideraba violatoria de la Constitución, el Presidente de la República mediante resolución, procedió a separar al señor Romeo Orlando Vásquez Velásquez de su cargo de Jefe del Estado Mayor Conjunto de las Fuerzas Armadas de Honduras.

Tanto el General Vásquez Velásquez, mediante abogado, como el Fiscal Especial para la Defensa de la Constitución René Mauricio Aceituno Ulloa, actuando a favor de los intereses generales de la sociedad y del orden jurídico constitucional, interpusieron sendos recursos de amparo contra la resolución presidencial mencionada, por ante la Sala Constitucional de la Corte Suprema de Justicia (Registro Nos. 881 y 883 09), la cual luego de acumular los recursos, en fecha 25 de junio de 2009 decidió con 
base en lo establecido en el artículo 40 de la Ley Constitutiva de las Fuerzas Armadas, contenida en el decreto 39-2001, de fecha 30 de abril del 2001, que es la Ley Especializada y aplicable en el caso; en los artículos 183, 245, 278, 280, 303, 313 atribución $5^{a}, 316,321$ y 323 de la Constitución de la República; en el artículo 8 de la Declaración Universal de los Derechos Humanos; en los artículos 8 y 25 de la Convención Americana sobre Derechos Humanos; en los artículos 1, 2, 4, 5, 7, 9 numeral 3 letra a), 41, 43, 44, 45, 48, 49, 59 numeral 1), 119,124 y demás aplicables de la Ley sobre Justicia Constitucional; a admitir los recursos de amparo de mérito, y "decretar bajo la responsabilidad de los recurrentes la suspensión provisional del acto reclamado”, ordenando "a la autoridad recurrida la inmediata remisión de los antecedentes formados al efecto o en su defecto el correspondiente informe dentro del plazo de un (01) día”. La Sala Constitucional, además, mandó que se diera "inmediato cumplimiento a lo ordenado" en la providencia que se ordenó comunicar al Presidente de la República.

\section{La vía de hecho presidencial y el nuevo desacato a las órdenes judiciales}

El día 25 de junio de 2009, el Presidente de la República, junto a varias personas, entre ellos funcionarios del Poder Ejecutivo, después de haber realizado un pronunciamiento público en las instalaciones de la Casa de Gobierno y que fue de conocimiento general a través de los diferentes medios de comunicación, anunciando que él tenía que realizar una misión, le pidió a la gente que se encontraba reunida en el lugar que lo acompañara, y se traslado a las instalaciones de la base aérea "Hernán Acosta Mejía”, lugar del cual el Presidente de la República, desacatando de nuevo las decisiones judiciales, retiró 814 cajas que contenían el material que sería utilizado para realizar la encuesta de opinión, que había ordenado realizar a nivel nacional el día domingo 28 de junio del 2009, y que había sido prohibida por el Poder Judicial.

\section{La acusación fiscal contra el Presidente de la República por diversos delitos}

Con motivo de todos los desacatos presidenciales ante las decisiones judiciales, y la actuación del Presidente de la República en contra de la Constitución, el día 25 de junio de 2009, el Fiscal General de la República, "en representación de los más altos intereses generales de la Sociedad Hondureña”, compareció ante la Corte Suprema de Justicia, formulando requerimiento fiscal en contra del Presidente de la República José Manuel Zelaya Rosales, a quien lo acusó como responsable, a título de autor, de los delitos contra la forma de gobierno, traición a la patria, abuso de autoridad y usurpación de funciones, en perjuicio de la administración pública y el Estado de Honduras, solicitando se librase contra él orden de captura, y luego de que se le comunicasen los hechos que se le imputaban, se le recibiera su declaración de imputado, se le suspendiera en el ejercicio del cargo, y se autorizase allanamiento de morada.

Las diversas actuaciones descritas por el Fiscal General ante la Corte, y atribuidas al Presidente de la República, consideró que se subsumían en los siguientes tipos penales:

Primero, en el Delito contra la Forma de Gobierno tipificado en el artículo 328,3 del Código Penal a cuyo efecto el Fiscal General consideró que si bien es cierto, el Gobier- 
no debe sustentarse en el principio de la democracia participativa, los únicos mecanismos de consulta a los ciudadanos en el ordenamiento de Honduras son el referéndum y el plebiscito, correspondiendo exclusivamente al Congreso Nacional conocer de los mismos y discutir las peticiones, las cuales deben ser aprobadas mediante decreto con el voto afirmativo de las dos terceras partes de la totalidad de sus miembros, en el cual se deben determinar los extremos de la consulta, correspondiendo al Tribunal Supremo Electoral la convocatoria correspondiente, siendo dicho órgano y no el Poder Ejecutivo, el único ente legitimado para convocar, organizar y dirigir las consultas a los ciudadanos (artículo 5 de la Constitución).

El Fiscal General consideró que siendo el tipo penal un delito de peligro abstracto y de mera actividad, basta la sola realización de actos encaminados fuera de las vías legales a cualesquiera de los fines estipulados en el artículo 328 del Código Penal, para que se configure el ilícito penal enunciado; siendo la publicidad difundida a través de los diferentes medios de comunicación, promoviendo la convocatoria para la consulta popular o encuesta de opinión popular, actuaciones que caen dentro del supuesto de la norma penal sustantiva, lesionando la Seguridad Interior del Estado como bien jurídico, objeto de protección, al constituir un acto encaminado fuera de las vías legales tendiente a despojar en parte las facultades que la constitución le atribuye al Congreso Nacional y al Tribunal Supremo Electoral.

Segundo, en el delito de Traición a la Patria, que el Fiscal General consideró tipificado en la Constitución de la República, derivado de los intentos de realizar reformas constitucionales contrariando lo dispuesto en los artículos 2, 4, 5, párrafo séptimo, 373 y 374; y estimó como dirigido a "afectar las bases constitucionales de la unidad del Estado como un Ente político, acciones que se consuman a través de actos encaminados fuera de las vías legales a despojar en parte las facultades atribuidas a los Poderes legalmente constituidos, indicando que ese era el caso concreto el Presidente de la República José Manuel Zelaya, quien, estimó

"suplantó la soberanía popular, la cual se ejerce en este País por representación de conformidad a lo que establece la norma constitucional, donde la soberanía corresponde al pueblo del cual emanan todos los Poderes del Estado, asimismo arrogándose facultades que nunca las tuvo en virtud que las mismas son de competencia del Congreso Nacional, en virtud de que a través de la emisión de tres decretos ejecutivos, convocó a la ciudadanía Hondureña a participar en una encuesta de opinión popular para que "el pueblo decida la convocatoria a una Asamblea Nacional Constituyente".

En tal sentido, consideró el Fiscal General que el hecho de convocar a una Asamblea Nacional Constituyente, "es evidente que con la misma se pretende derogar la actual Constitución”, y conforme a los artículos 373, 374 y 375 de la Constitución, "bajo ninguna circunstancia se podrá dictar y aprobar una nueva constitución porque esta traería consigo la reforma de artículos pétreos, mismos que no podrán reformarse en ningún caso", todo lo cual configura una "conducta contraria a derecho por parte 
del Ciudadano Presidente de la República, suplantando al Poder Legislativo a convocado a la Ciudadanía Hondureña a la encuesta de opinión".

Tercero, en el delito de Abuso de Autoridad regulado en el artículo 349,1 del Código Penal y que sanciona al funcionario o empleado público "que se niegue a dar el debido cumplimiento a órdenes, sentencias, providencias, acuerdos o decretos dictados por autoridades judiciales o administrativas dentro de los límites de sus respectivas competencias y con las formalidades legales...”. En este caso, consideró el Fiscal General que se reúnen los elementos objetivos de este tipo penal, "en vista de que el Ciudadano Presidente de la República en flagrante omisión a los apercibimientos emanados a través de las comunicaciones libradas por el Juzgado de lo Contencioso Administrativo", incumplió con las disposiciones contenidas relativas a la ejecución de la sentencia, y a pesar de haber sido apercibido, hizo caso omiso, y "con pleno conocimiento y voluntad, procedió a realizar actos contrarios a la sentencia dictada”.

Cuarto, en el tipo penal de Usurpación de Funciones conforme el artículo 354 del Código Penal, ya que conforme al artículo 15, numeral 5 y 8 de la Ley Electoral y de las Organizaciones Políticas, es atribución del Tribunal Supremo Electoral, organizar dirigir, administrar y vigilar los procesos electorales y consultas populares; así como convocar a elecciones, referéndums y plebiscitos; y además, conforme al artículo 5, quinto párrafo de la Constitución, "corresponde únicamente al Tribunal Supremo Electoral, convocar, organizar y dirigir las consultas a los ciudadanos señalados en los párrafos anteriores". En el caso, consideró el Fiscal General que el hecho del Presidente de la República de emitir tres decretos, "referentes a la realización de una consulta, llamada posteriormente encuesta de opinión", cuyo objetivo era "consultar si las personas estaban de acuerdo con la instalación de una cuarta urna en las elecciones generales para decidir si se convoca a una Asamblea Nacional Constituyente que emita una nueva Constitución de la República”, lo que era atribución exclusiva del Tribunal Supremo Electoral.

El Fiscal General, además, destacó que en la gama de delitos imputados, el Presidente de la República además "vulneró el principio de legalidad el cual se encuentra descrito en el artículo 321 Constitución de la República, que establece: «Los servidores del Estado no tienen más facultades que las que expresamente les confiere la ley..." ejerciendo arbitrariamente la función pública con desviación y abuso de poder.

Con fundamento en lo que expuso ante la Corte Suprema de Justicia, el Fiscal General consideró que debido a la alta investidura que como alto Funcionario del Estado ostentaba el presidente "y existiendo un peligro de fuga por la gravedad de la pena que pueda imponérsele" como resultado del proceso, solicitó se ordenase el allanamiento de Morada para la aprehensión del acusado José Manuel Zelaya Rosales. El Fiscal General, además, para evitar la impunidad y en virtud de que conforme al artículo 33 de la Ley de la Administración Pública los Secretarios de Estado son colaboradores del Presidente de la República, y teniendo el titular de la Secretaria de Estado en los Despachos de Seguridad a través de la Policía Nacional, la facultad legal de hacer efectivas las órdenes de captura emanadas de autoridad competente, debido 
al conflicto de intereses y al temor fundado que tenía el Ministerio Público que no se le diera cumplimento a la orden Judicial, solicitó de la Corte Suprema que se instruyera a las Fuerzas Armadas de Honduras a través del Jefe del Estado Mayor Conjunto, la facultad de hacer que se cumplan los mandatos de la constitución, las leyes y Reglamentos le imponen a las Fuerzas Armadas, y procedieran hacer efectiva la orden de captura del acusado Presidente.

Con fecha 26 de junio de 2009, conforme a lo alegado y solicitado por el Fiscal General, la Corte Suprema de Justicia resolvió y en consecuencia se dirigió al Jefe del Estado Mayor Conjunto de las Fuerzas Armadas, General de División, Romeo Vásquez Velásquez, ordenando la captura del Presidente de la República de Honduras, José Manuel Zelaya Rosales, "a quien se le supone responsable de los delitos de: contra la forma de gobierno, traición a la patria, abuso de autoridad y usurpación de funciones en perjuicio de la Administración Pública y del Estado de Honduras”. La Corte Suprema también se dirigió en la misma fecha, al Estado Mayor Conjunto de las Fuerzas Armadas de Honduras, ordenando proceder en el momento pertinente al allanamiento de la vivienda del Presidente de la República de Honduras, José Manuel Zelaya Rosales,

"entre las seis de la mañana y las seis de la tarde y ponerlo a la orden de la autoridad correspondiente por suponerlo responsable de la comisión de los hechos delictivos: CONTRA LA FORMA DE GOBIERNO, TRAICIÓN A LA PATRIA, ABUSO DE AUTORIDAD Y USURPACIÓN DE FUNCIONES en perjuicio de la Administración Publica y del Estado de Honduras, lo anterior a raíz del requerimiento fiscal presentado en esta Corte por parte del Ministerio Publico".

El día 28 de junio de 2009, sin embargo, la orden judicial no fue ejecutada tal como se ordenó judicialmente, y el Presidente Zelaya después de haber sido detenido en su residencia durante la noche, fue ilegalmente extrañado del país y un avión lo trasladó a Costa Rica, indudablemente en violación de lo previsto en los artículos 81 y 102 de la Constitución.

Al día siguiente, 29 de junio de 2009, la Corte Suprema de Justicia, consideró que como era "de público y notorio conocimiento que el ciudadano José Manuel Zelaya Rosales, ha dejado de ostentar la condición de Presidente Constitucional de la República", carácter por el cual había sido presentado el Requerimiento Fiscal ante el Supremo Tribunal de Justicia, para que se le siguiese el procedimiento establecido en la normativa procesal penal que regula el enjuiciamiento criminal para los más altos funcionarios del Estado; al haber dejado el Presidente Zelaya de ostentar la condición de alto funcionario del Estado, consideró la Corte que entonces no era procedente seguir su enjuiciamiento de conformidad a los artículos 414, 415, 416, 417 del Código Procesal Penal, debiéndose en consecuencia, conocerse por la vía del procedimiento penal ordinario, "a fin de garantizarle así las reglas propias del debido proceso al imputado". Como consecuencia, resolvió, además de tener por presentado el Requerimiento Fiscal junto con los documentos que se acompañaron, remitirlo al Juzgado de Letras Unificado de lo Penal de Tegucigalpa, Francisco Morazán, para que se continuase con el procedimiento ordinario establecido en el Código Procesal Penal. 
En esta decisión, la Corte Suprema, sin embargo, no suministró fundamento jurídico alguno ni indicó con base en qué acto jurídico el Presidente Zelaya el día 28 de junio había "dejado de ostentar la condición de Presidente Constitucional de la República"; limitándose a decir que ello era de "de público y notorio conocimiento". Lo que había ocurrido, en realidad, era que había sido expatriado (eso era quizás lo público y notorio) en forma inconstitucional, pero no por ello habría dejado de ser Presidente Constitucional. En este aspecto, el tema que habría quedado pendiente de resolver es si, para el caso de que el Presidente expatriado llegase a regresar al país, si debería continuar ser procesado por la Corte Suprema de Justicia, en virtud de su condición de Presidente, y no por parte de un tribunal penal ordinario como ex funcionario.

\section{EL JUEZ CONTENCIOSO ADMINISTRATIVO COMO JUEZ CONSTITUCIONAL Y LA DEFENSA DE LA DEMOCRACIA}

En Honduras, sin la menor duda, el Juzgado de Letras Contencioso Administrativo con sede en Tegucigalpa, al ejercer el control de la constitucionalidad e ilegalidad sobre los actos administrativos dictados por el Presidente de Honduras relativos a la consulta popular sobre la convocatoria de una Asamblea Nacional Constituyente, actuó como juez constitucional, ejerciendo las competencias que le asigna la Ley 29/ 1998 reguladora de la Jurisdicción Contencioso Administrativa; competencia de control que, lamentablemente, aún por la vía del recurso contencioso administrativo de interpretación, la Sala Político Administrativa de la Corte Suprema de Venezuela actuando como juez contencioso administrativo diez años antes se abstuvo de ejercer, cuando le tocó resolver sobre la misma inconstitucional situación: la convocatoria de un referendo consultivo por el Presidente de la República sin estar previsto este mecanismo de reforma constitucional en el texto de la Constitución.

De las previsiones constitucionales tanto en Honduras como en Venezuela, en efecto, el ejercicio de la justicia constitucional corresponde conforme a la Constitución, no sólo a la Jurisdicción Constitucional que en ambos países ejercen las Salas Constitucionales del Supremo Tribunal, sino a la Jurisdicción Contencioso Administrativa, al ejercer su competencia de anulación de los actos administrativos de efectos generales o particulares contrarios a derecho, es decir, contrarios a la Constitución, a las leyes o a las demás fuentes del derecho administrativo. ${ }^{21}$ Es decir, todos los jueces contencioso administrativos, conforme al artículo 259 de la Constitución de Venezuela y a la Ley reguladora de la Jurisdicción Contencioso Administrativa en Honduras, tienen potestad para declarar la nulidad de los actos administrativos, no sólo por ilegalidad sino por inconstitucionalidad, ejerciendo la justicia constitucional.

21 Véase Allan R. Brewer-Carías, La Justicia Constitucional, Universidad Nacional Autónoma de México, México, 2007, pp. 447 ss.; y La Justicia Contencioso administrativa, Tomo VII, Instituciones Políticas y Constitucionales, Editorial Jurídica Venezolana, Caracas, San Cristóbal, 1996, pp. 26 ss. 
De lo anterior resulta que así como debe diferenciarse la Jurisdicción Constitucional que se atribuye a las Salas Constitucionales, de la función de justicia constitucional que corresponde conforme a las Constituciones de Venezuela (artículo 334) y Honduras (artículo 320) a todos los jueces; también, debe establecerse claramente la diferenciación entre la Jurisdicción Constitucional y la Jurisdicción Contencioso Administrativa, la cual radica en la competencia por el objeto que se atribuye a los Tribunales que las componen: la Jurisdicción Constitucional que corresponde a los Tribunales Supremos en Sala Constitucional, tiene por objeto conocer de las acciones de nulidad por inconstitucionalidad contra las leyes y demás actos de rango legal o ejecución directa e inmediata de la Constitución; en cambio, la Jurisdicción Contencioso Administrativa que corresponde a los tribunales de la misma conforme a la Ley, tiene por objeto, entre otros, conocer de las acciones de nulidad por inconstitucionalidad o ilegalidad contra los actos administrativos generales o particulares, que siempre son de rango sub legal; o como lo precisa la Ley reguladora de la Jurisdicción Contencioso Administrativa de Honduras, los tribunales de la Jurisdicción "conocerán de las pretensiones que se deduzcan en relación con la actuación de las Administraciones públicas sujeta al Derecho Administrativo, con las disposiciones generales de rango inferior a la Ley y con los Decretos legislativos cuando excedan los límites de la delegación” (art. 1). Por ello, de acuerdo con el artículo 76,1 de la Ley Justicia Constitucional de Honduras (2004), la acción de inconstitucionalidad procede "contra las leyes y otras normas de carácter y aplicación general no sometidos al control de la jurisdicción contencioso administrativa, que infrinjan preceptos constitucionales". ${ }^{22}$

Esto implica que ambas Jurisdicciones se diferencian por el objeto de las acciones y no por el motivo de las mismas: la Jurisdicción Constitucional conoce de la nulidad de las leyes y demás actos de rango legal o de ejecución directa e inmediata de la Constitución; en cambio, la Jurisdicción Contencioso Administrativa, conoce de la nulidad de los actos administrativos, que son de rango sub-legal, sea cual fuere el motivo de impugnación. Así se expuso, por ejemplo, en la sentencia $\mathrm{N}^{\circ} 6$ de 27 de enero de $2000^{23}$ de la Sala Constitucional del Tribunal Supremo de Venezuela, señalando que "La Constitución vigente distingue claramente la jurisdicción constitucional de la contencioso administrativa, delimitando el alcance de ambas competencias en atención al objeto de impugnación, es decir, al rango de los actos objeto de control y no a los motivos por los cuales se impugnan". ${ }^{24}$ En otros términos, la Sala Constitucional de Venezuela, en la sentencia $\mathrm{N}^{\circ} 194$ de 4 de abril de 2000, así:

22 Véase en general sobre la ley de Justicia Constitucional de Honduras, nuestros comentarios, Allan R. Brewer-Carías, "El sistema de justicia constitucional en Honduras" en El sistema de Justicia Constitucional en Honduras (Comentarios a la Ley sobre Justicia Constitucional), Instituto Interamericano de Derechos Humanos, Corte Suprema de Justicia. República de Honduras, San José, 2004, pp. 1-148; y "La reforma del sistema de justicia constitucional en Honduras", en Revista Iberoamericana de Derecho Procesal Constitucional. Proceso y Constitución (Directores Eduardo Ferrer Mac-Gregor y Aníbal Quiroga León), $\mathrm{N}^{\circ}$ 4, 2005, Editorial Porrúa, México, pp. 57-77.

23 Véase en Revista de Derecho Público, N 81, (enero-marzo), Editorial Jurídica Venezolana, Caracas, 2000, p. 213.

24 Criterio que se ratificó expresamente por la misma la Sala, en sentencia $N^{\circ} 194$ de 4 de abril de 2000 , en Revista de Derecho Público, N 82, Editorial Jurídica Venezolana, Caracas, 2000. 
"El criterio acogido por el Constituyente para definir las competencias de la Sala Constitucional, atiende al rango de las actuaciones objeto de control, esto es, que dichas actuaciones tienen una relación directa con la Constitución que es el cuerpo normativo de más alta jerarquía dentro del ordenamiento jurídico en un Estado de derecho contemporáneo. Así las cosas, la normativa constitucional aludida imposibilita una eventual interpretación que tienda a identificar las competencias de la Sala Constitucional con los vicios de inconstitucionalidad que se imputen a otros actos o con las actuaciones de determinados funcionarios u órganos del Poder Público". ${ }^{25}$

De lo anterior, la Sala concluyó precisando su propia competencia así:

"la Sala Constitucional, en el ejercicio de la jurisdicción constitucional, conoce de los recursos de nulidad interpuestos contra los actos realizados en ejecución directa de la Constitución o que tengan forma de ley. De allí que, en el caso de autos, al tratarse el reglamento impugnado de un acto de rango sublegal, esta Sala Constitucional carece de competencia para controlar su conformidad a Derecho, ya que tal competencia corresponde a la Jurisdicción Contencioso Administrativa. Así se decide". ${ }^{26}$

Estos mismos criterios se aplican en Honduras donde la Sala Constitucional, conforme al artículo 319,12 le corresponde la competencia para "declarar la inconstitucionalidad de las leyes en la forma y casos previstos en esta Constitución”, como competencia “originaria y exclusiva" (artículo 184), previéndose que "las sentencias que declaren la inconstitucionalidad de una norma será de ejecución inmediata y tendrá efectos generales, y por tanto derogarán la norma inconstitucional' (art. 316). Con esta previsión incorporada en la Constitución en la reforma de 2000 se pasó así de un método de control concentrado de constitucionalidad de las leyes con efectos inter partes, a un método de control concentrado con efectos generales, erga omnes, permaneciendo previsto el método difuso de control de la constitucionalidad de las leyes (art. 320), aun cuando sin operatividad, como potestad atribuida a todos los jueces para desaplicar las leyes que consideren inconstitucionales al decidir los casos concretos que deben resolver.

Con base en estos poderes del juez contencioso administrativo de actuar como juez constitucional, controlando la constitucionalidad y legalidad de las actuaciones del Poder Ejecutivo, fue que se desarrolló en Honduras el proceso judicial contencioso administrativo contra los decretos presidenciales de marzo-mayo de 2009 para la convocatoria de una consulta popular o encuesta de opinión que encubrían una propuesta de referendo "decisorio" sobre la convocatoria de una Asamblea Nacional Constituyente, y que condujeron finalmente a la orden de detención y a la orden de enjuiciamiento del Presidente de la República, José Manuel Zelaya, entre otros hechos y actos, por desacato a las decisiones del Poder Judicial.

25 Criterio que ratificó lo que había decidido en sentencia de 27 de enero de 2000 (Caso Milagros Gómez y otros. Véase en Revista de Derecho Público, N 82, Editorial Jurídica Venezolana, Caracas, 2000.

26 Véase en Revista de Derecho Público, N 82, Editorial Jurídica Venezolana, Caracas, 2000. 
El control judicial desarrollado por la Jurisdicción Contencioso Administrativa, en todo caso, puede decirse que fue un proceso de defensa de la democracia; sin embargo, llama la atención que al ejercerse el control de los actos del Presidente de la República dictados en violación de la Constitución y sobre las vías de hecho en que incurrió contrarias al Poder Judicial y al ordenamiento jurídico de Honduras, en ninguna de las actas procesales fundamentales del proceso se haya usado la palabra "democracia". Sin embargo, en un Estado Constitucional, la defensa de la Constitución es siempre defensa de la democracia entendida como el régimen político que busca asegurar que el ejercicio del poder público por el pueblo, como titular que es de la soberanía, se haga en la forma prescrita en la Constitución, tanto en forma indirecta a través de representantes electos (democracia representativa), como en forma directa manifestando su voluntad para la toma de decisiones mediante referendo (democracia directa).

Para asegurar que el ejercicio de ese poder no sea ni abusivo ni arbitrario, el propio pueblo lo somete a límites establecidos tanto en la Constitución del Estado que él mismo ha adoptado como norma suprema, como en la legislación que deben sancionar sus representantes en los órganos del Estado. La Constitución y las leyes contienen, así, los límites que el propio pueblo se impone a sí mismo y a sus representantes para ejercer el poder público, por lo que todo control respecto de la sumisión de los órganos del Estado a la Constitución, es un control de defensa a la propia democracia. Por ello, el Estado que se organiza en una Constitución adoptada en una sociedad democrática, es esencialmente un Estado sometido a controles.

Para garantizar ese Estado y la propia democracia es que se establece un sistema que permita la posibilidad de controlar el ejercicio del poder, de manera que los propios órganos que ejercen el poder en el Estado puedan, mediante su división y distribución, frenar el ejercicio mismo del poder, y así los diversos poderes del Estado puedan limitarse mutuamente. Por ello la existencia de sistemas de justicia constitucional y justicia contencioso administrativa desarrollado en todos los países democráticos.

La democracia como régimen político, por tanto, es mucho más que la sola elección de representantes mediante votación popular, o de la convocatoria a referendos, siendo la democracia representativa, por supuesto, de su esencia, sin la cual como régimen político, no podría existir. Tal como lo precisó la Carta Democrática Interamericana adoptada en la Asamblea General de la Organización de Estados Americanos, en Lima, el 11 de septiembre de 2001: además de la celebración de elecciones periódicas, libres, justas y basadas en el sufragio universal y secreto, como expresión de la soberanía del pueblo, la democracia representativa contiene acumulativamente una serie de otros elementos esenciales, sin los cuales no puede existir como régimen político, entre los cuales está, el respeto a los derechos humanos y las libertades fundamentales, el acceso al poder y su ejercicio con sujeción al Estado de derecho; el régimen plural de partidos y organizaciones políticas; y la necesaria existencia de la separación e independencia de los poderes públicos (artículo 3). Además, la misma Carta definió que el ejercicio de la democracia, acumulativamente contiene estos otros componentes fundamentales, que son: la transparencia de las actividades guberna- 
mentales, la probidad, la responsabilidad de los gobiernos en la gestión pública, y el respeto por los derechos sociales y la libertad de expresión y de prensa; la subordinación constitucional de todas las instituciones del Estado a la autoridad civil legalmente constituida y el respeto al estado de derecho de todas las entidades y sectores de la sociedad (artículo 4). La democracia, por tanto, como se dijo, es mucho más que las solas elecciones y votaciones, y entre sus elementos quizás el más esencial es el que se refiere a la separación e independencia de los Poderes Públicos, ya que el mismo es el que asegura que los otros factores de la propia democracia puedan ser una realidad política. ${ }^{27}$ En otros términos, sin control del poder no sólo no hay ni puede haber real democracia ni efectivo Estado de derecho, sino que no se puede lograr la efectiva vigencia de todos los mencionados factores esenciales de la democracia. Es decir, sólo controlando al Poder es que puede haber elecciones completamente libres y justas, y representatividad efectiva; sólo controlando al poder es que puede haber pluralismo político; sólo controlando al Poder es que puede haber efectiva participación democrática; sólo controlando al Poder es que puede asegurarse una efectiva transparencia en el ejercicio del gobierno, con exigencia de la rendición de cuentas por parte de los gobernantes; sólo controlando el Poder es que se puede asegurar un gobierno sometido a la Constitución y las leyes, es decir, un Estado de derecho; sólo controlando el Poder es que puede haber un efectivo acceso a la justicia y esta pueda funcionar con efectiva autonomía e independencia; y sólo controlando al Poder es que puede haber real y efectiva garantía de respeto a los derechos humanos.

Al contrario demasiada concentración y centralización del poder, como ocurre en cualquier gobierno autoritario, así tenga origen electoral, si no hay controles efectivos sobre los gobernantes, y peor aún, si estos tienen o creen tener apoyo popular, inevitablemente conduce a la corta o a la larga a la tiranía. Y esa fue la historia de la humanidad durante la primera mitad del siglo pasado, que nos mostró precisamente a tiranos que usaron el voto de la mayoría para acceder al poder y desde allí aplicaron el autoritarismo para acabar con la propia democracia y con todos sus elementos, comenzando por el respeto a los derechos humanos; y es la historia reciente en América Latina que nos muestra la emergencia de regímenes autoritarios usando y manipulando fraudulentamente las previsiones constitucionales y los medios electorales, como ha sido el caso de Venezuela, para violar la Constitución y destruir la democracia. ${ }^{28}$

27 Véase sobre la Carta Democrática Interamericana y la crisis de la democracia en Venezuela, Allan R. Brewer-Carías, La crisis de la democracia venezolana. La Carta Democrática Interamericana y los sucesos de abril de 2002, Ediciones El Nacional, Caracas, 2002, pp. 137 y ss.

28 Véase Allan R. Brewer-Carías, "La demolición del Estado de Derecho en Venezuela Reforma Constitucional y fraude a la Constitución (1999-2009)", en El Cronista del Estado Social y Democrático de Derecho, $\mathrm{N}^{\circ}$ 6, Editorial lustel, Madrid, 2009, pp. 52-61; "El autoritarismo establecido en fraude a la Constitución y a la democracia y su formalización en "Venezuela mediante la reforma constitucional. (De cómo en un país democrático se ha utilizado el sistema eleccionario para minar la democracia y establecer un régimen autoritario de supuesta "dictadura de la democracia" que se pretende regularizar mediante la reforma constitucional)" en el libro Temas constitucionales. Planteamientos ante una Reforma, Fundación de Estudios de Derecho Administrativo, FUNEDA, Caracas, 2007, pp. 13-74; "Constitution Making in Defraudation of the Constitution and Authoritarian Government in Defraudation of Democracy. The Recent Venezuelan Experience", en Lateinamerika Analysen, 19, 1/2008, GIGA, Germa Institute of Global and Area Studies, Institute of Latin American Studies, Hamburg, 2008, pp. 119-142. 
En Honduras, sin duda, funcionaron los controles, y las actividades del Presidente Zelaya violatorias de la Constitución, fueron controladas por los tribunales de la Jurisdicción Contencioso Administrativa, la cual demostró tener una autonomía e independencia que muchas jurisdicciones de otros países podrían envidiar. En este caso, fue dicha Jurisdicción la que defendió la Constitución y la democracia; y el desacato a sus decisiones, ajustadas a derecho, fueron las que condujeron a la Corte Suprema de Justicia a ordenar el procesamiento del Presidente. Lamentablemente, al final, como se dijo, la orden judicial dada a las Fuerzas Armadas por la Corte Suprema, no fue ejecutada como ordenado, y el Presidente Zelaya fue ilegalmente extrañado del país en violación de lo previsto en los artículos 81 y 102 de la Constitución, con las consecuencias internacionales conocidas.

New York, julio de 2009. 